
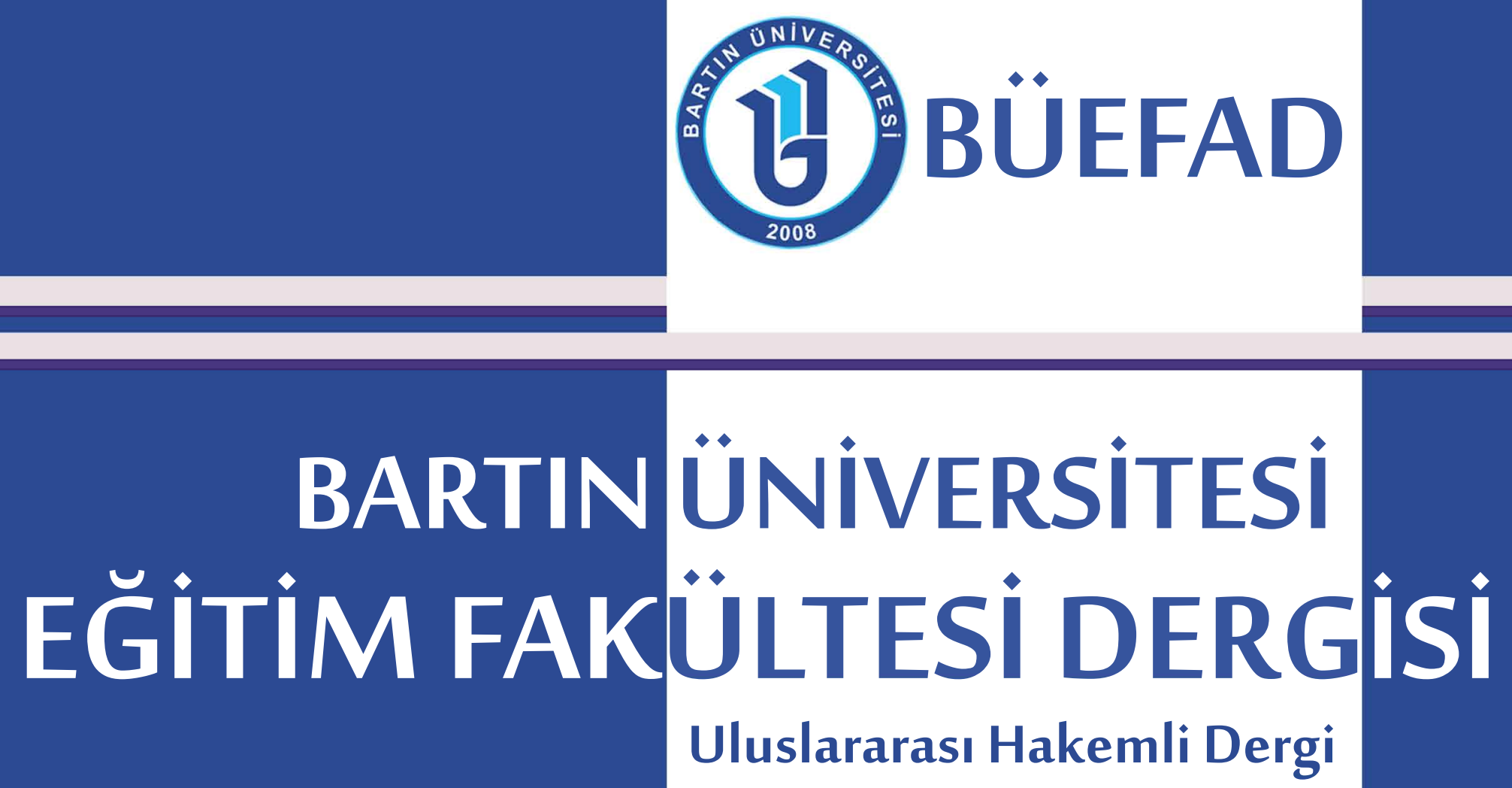

\section{- AYRI BASIM -}

Dr. Gizem KARAOĞLAN YILMAZ

Dr. Ramazan YILMAZ

Arş. Gör. Barış SEZER

Üniversite Öğrencilerinin Güvenli Bilgi ve İletişim Teknolojisi Kullanım Davranışları ve Bilgi Güvenliği Eğitimine Genel Bir Bakış

\section{- SPECIAL EDITION - \\ Gizem KARAOGLAN YILMAZ \\ Ramazan YILMAZ \\ RA Baris SEZER}

Secure Information and Communication Technology Usage Behavior of University Students and an Overview to Information Security Training
BARTINUNIVERSITY JOURNAL

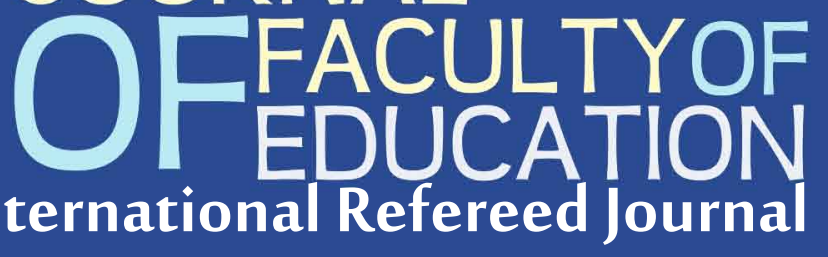

Cilt/Volume: $3 \quad$ Sayı/Issue: 1

Yaz/Summer 2014 ISSN 1308-7177
ProcessForm

Objectives

Pre-Service

okuma 1 echerperiments 10 gy

Profession

Verbal Supervision

Study Investigating Turkish

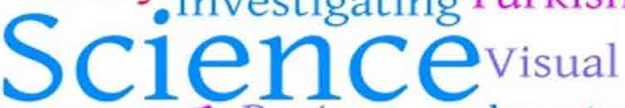

Iอ

Candidatestomaras

Education Approaches ölçeğinin

Digital Supervisors

Teacher Mathematics Profiles

Examination Processing

Assisted Reliability Alg1sı

ÖzyeterlilikEleștirel

Attitudes ${ }^{\text {Style }}$

2014-3

Teaching Features University

Güvenirlik Geçerlilik

Çalışması ınalysis

Example Speech 


\section{BARTIN ÜNIVERSİTesi EĞítim FAKüLTESI DERgisi}

BARTIN UNIVERSITY JOURNAL OF FACULTY OF EDUCATION

Cilt/ Volume: 3, Say1/Issue: 1, Yaz / Summer 2014

ISSN:1308-7177

\section{$\underline{\text { Sahibi }}$}

Bartın Üniversitesi Eğitim Fakültesi Adına Prof. Dr. Firdevs GÜNEŞ (Dekan)

Editör

Yrd. Doç. Dr. Sedat BALYEMEZ

\section{Alan Editörleri}

Doç. Dr. Çetin SEMERCi

Doç. Dr. Necati HIRÇA

Doç. Dr. Nuriye SEMERCi

Yrd. Doç. Dr. Ayşe Derya IŞIK

Yrd. Doç. Dr. Meliha KÖSE

Yrd. Doç. Dr. Neslihan USTA

Yrd. Doç. Dr. Sevan NART

Yrd. Doç. Dr. Sinem TARHAN

Yrd. Doç. Dr. Süreyya GENÇ

Yabancı Dil Sorumlusu

Yrd. Doç. Dr. Özge GÜN

\section{Yayıma Hazırlık}

Arş. Gör. Arzu ÇEVIK

Arş. Gör. Ömer KEMiksiz

\section{Sekretarya}

Arş. Gör. Hasan Basri KANSIZOĞLU

\section{Teknik Sorumlular}

Arş. Gör. Barış ÇUKURBAŞı

Arş. Gör. Fatma Gizem KARAOĞLAN YILMAZ

\section{İetişim}

Bartın Üniversitesi Eğitim Fakültesi

74100 BARTIN - TÜRKIYE

e-posta: buefad@bartin.edu.tr

Tel: +903782235219

Bartın Üniversitesi Eğitim Fakültesi Dergisi (BÜEFAD), yılda iki kez yayımlanan uluslararası hakemli bir dergidir. Yazıların sorumluluğu, yazarlarına aittir.
Owner

On Behalf of Bartin University Faculty of Education Prof. Firdevs GUNES (Dean)

$\underline{\text { Editor }}$

Asst. Prof. Sedat BALYEMEZ

Field Editors

Assoc. Prof. Cetin SEMERCI

Assoc. Prof. Necati HIRCA

Assoc. Prof. Nuriye SEMERCI

Asst. Prof. Ayse Derya ISIK

Asst. Prof. Meliha KOSE

Asst. Prof. Neslihan USTA

Asst. Prof. Sevan NART

Asst. Prof. Sinem TARHAN

Asst. Prof. Sureyya GENC

Foreign Language Specialist

Asst. Prof. Ozge GUN

Preparing for Publication

RA. Arzu CEVIK

RA. Omer KEMIKSIZ

Secretary

RA. Hasan Basri KANSIZOGLU

$\underline{\text { Technical Assistants }}$

RA. Baris CUKURBASI

RA. Fatma Gizem KARAOGLAN YILMAZ

Contact

Bartin University Faculty of Education 74100 BARTIN - TURKEY

e-mail: buefad@bartin.edu.tr

Tel: +90 3782235219

Bartin University Journal of Faculty of Education (BUJFED) is a international refereed journal that is published two times a year. The responsibility lies with the authors of papers. 


\section{DiZINLENME VE LISTELENME / INDEXING AND LISTING}

Bartın Üniversitesi Eğitim Fakültesi Dergisi, aşağıdaki indeksler tarafından dizinlenmekte ve listelenmektedir. / Bartin University Journal of Faculty of Education is indexed and listed by the following indexes.

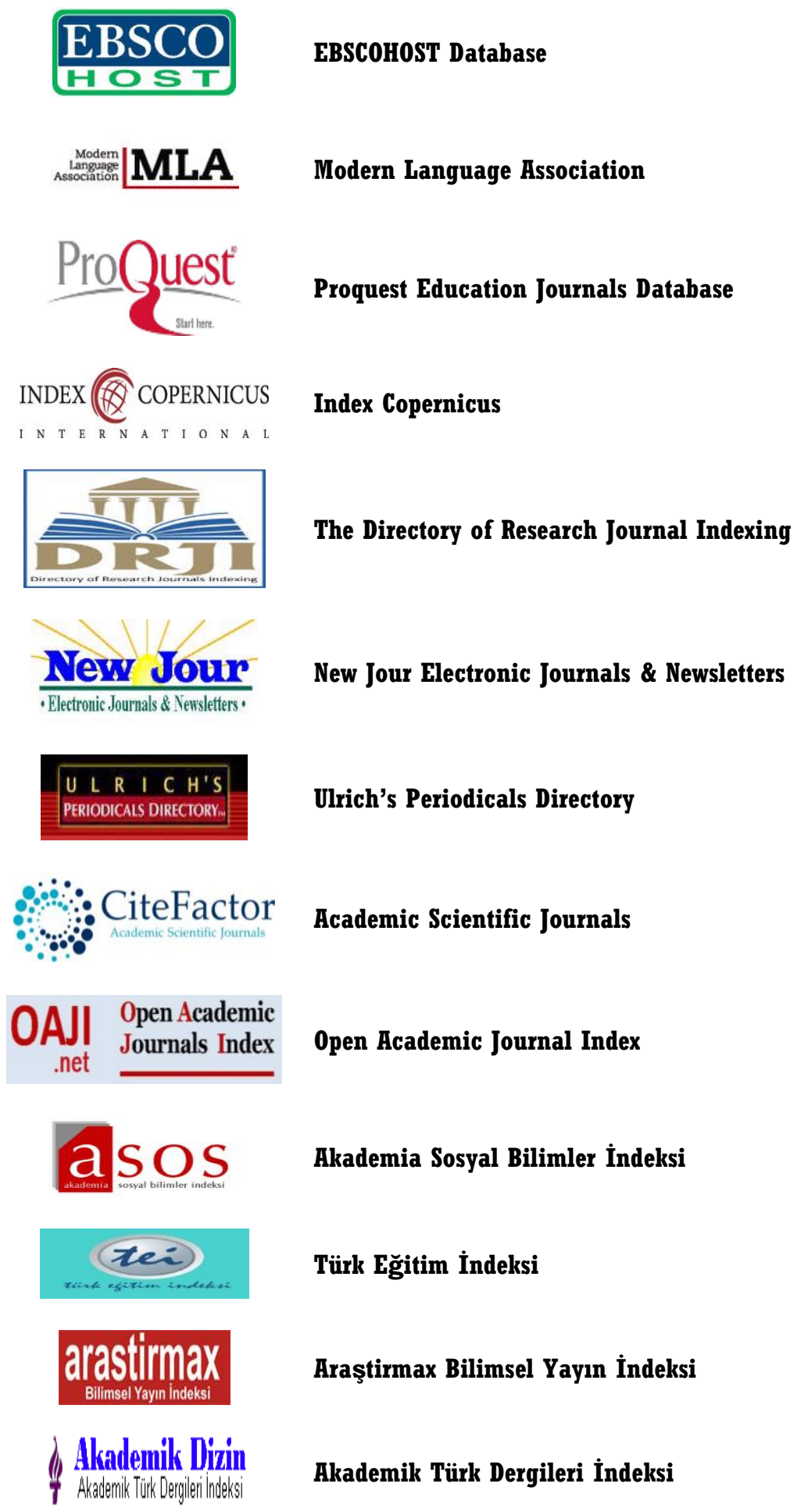


YAYIN DANIŞMA KURULU / EDITORIAL ADVISORYBOARD

Prof. Dr. Ahmet ARIKAN

Prof. Dr. Ahmet GÜNŞEN

Prof. Dr. Ahmet SABAN

Prof. Dr. Aziz KILINÇ

Prof. Dr. Bilgin Ünal iBRET

Prof. Dr. Cemal TOSUN

Prof. Dr. Firdevs GÜNEŞ

Prof. Dr. Firdevs KARAHAN

Prof. Dr. Ahmet KIRKILIÇ

Prof. Dr. Hayati AKYOL

Prof. Dr. Hüseyin ALKAN

Prof. Dr. M. Fatih TAŞAR

Prof. Dr. Mimar TÜRKKAHRAMAN

Prof. Dr. Murat ÖZBAY

Prof. Dr. Ramazan KAPLAN

Prof. Dr. Recai DOĞAN

Prof. Dr. Safure BULUT

Prof. Dr. Sebahattin ARIBAŞ

Prof. Dr. Selahattin TURAN

Prof. Dr. Selma YEL

Prof. Dr. Şefik YAŞAR

Prof. Dr. Yavuz TAŞKESENLIGIL

Doç. Dr. Bahri ATA

Doç. Dr. Çavuş ŞAHIN

Doç. Dr. Çetin SEMERCi

Doç. Dr. Emine KOLAÇ

Doç. Dr. Erol DURAN

Doç. Dr. Eyyüp COŞKUN

Doç. Dr. Kubilay YAZICI

Doç. Dr. Neşe TERTEMiz

Doç. Dr. Nuriye SEMERCi

Doç. Dr. Sabri SIDEKLi

Doç. Dr. Tolga GÜYER
Gazi Üniversitesi

Trakya Üniversitesi

N. Erbakan Üniversitesi

ÇOMÜ

Kastamonu Üniversitesi

Ankara Üniversitesi

Bartın Üniversitesi

Sakarya Üniversitesi

Atatürk Üniversitesi

Gazi Üniversitesi

Dokuz Eylül Üniversitesi

Gazi Üniversitesi

Akdeniz Üniversitesi

Gazi Üniversitesi

Bartın Üniversitesi

Ankara Üniversitesi

ODTÜ

Adıyaman Üniversitesi

Osmangazi Üniversitesi

Gazi Üniversitesi

Anadolu Üniversitesi

Atatürk Üniversitesi

Gazi Üniversitesi

ÇOMÜ

Bartın Üniversitesi

Anadolu Üniversitesi

Uşak Üniversitesi

Mustafa Kemal Üniversitesi

Niğde Üniversitesi

Gazi Üniversitesi

Bartın Üniversitesi

Muğla S. Koçman Üniversitesi

Gazi Üniversitesi 


\section{BU SAYININ HAKEMLERI / REFEREES OFTHIS ISSUE}

Prof. Dr. Ahmet KAÇAR

Prof. Dr. Adnan BAKi

Prof. Dr. Fatma AÇIK

Prof. Dr. Firdevs GÜNEŞ

Prof. Dr. Firdevs KARAHAN

Prof. Dr. Hasan BACANLI

Prof. Dr. Yusuf BUDAK

Doç. Dr. Ali TAŞ

Doç. Dr. Çetin SEMERCi

Doç. Dr. Ebru KILIÇ ÇAKMAK

Doç. Dr. Eyyüp COŞKUN

Doç. Dr. Halit KARATAY

Doç. Dr. Gökhan DEMIRCioĞLU

Doç. Dr. Levent ERASLAN

Doç. Dr. Mehmet Ali ÇAKMAK

Doç. Dr. Mehmet Altan KURNAZ

Doç. Dr. Mustafa ULUSOY

Doç. Dr. Mübin KIYICI

Doç. Dr. Necati HIRÇA

Doç. Dr. Nuriye SEMERCi

Doç. Dr. Orhan AKINOĞLU

Doç. Dr. Özay KARADAĞ

Doç. Dr. Özlem ÇAKMAK

Doç. Dr. Sabri SIDEKLI

Doç. Dr. Yüksel GÖĞEBAKAN

Yrd. Doç. Dr. Abdullah Çağrı BiBBER

Yrd. Doç. Dr. Ahmet YIKMIŞ

Yrd. Doç. Dr. Ahmet AKKAYA

Yrd. Doç. Dr. Ali Rıza ŞEKERCi

Yrd. Doç. Dr. Aslıhan SABAN

Yrd. Doç. Dr. Aynur KOLBURAN GEÇER

Yrd. Doç. Dr. Ayşe Derya IŞIK

Yrd. Doç. Dr. Ayşe GÜLER

Yrd. Doç. Dr. Burcu DUMAN

Yrd. Doç. Dr. Cemal TOSUN

Yrd. Doç. Dr. Çığıl AYKUT

Yrd. Doç. Dr. Devrim AKGÜNDÜZ

Yrd. Doç. Dr. Fulya TOPÇUOĞLU ÜNAL

Yrd. Doç. Dr. Gamze Elif TANINMIŞ

Yrd. Doç. Dr. Güliz AYDIN

Yrd. Doç. Dr. İbrahim GÖKTAŞ

Yrd. Doç. Dr. İlhan YALÇIN
Kastamonu Üniversitesi

Karadeniz Teknik Üniversitesi

Gazi Üniversitesi

Bartın Üniversitesi

Sakarya Üniversitesi

Yıldız Teknik Üniversitesi

Gazi Üniversitesi

Kırıkkale Üniversitesi

Bartın Üniversitesi

Gazi Üniversitesi

Mustafa Kemal Üniversitesi

Abant İzzet Baysal Üniversitesi

Ondokuz Mayıs Üniversitesi

Kırıkkale Üniversitesi

Gazi Üniversitesi

Kastamonu Üniversitesi

Gazi Üniversitesi

Sakarya Üniversitesi

Bartın Üniversitesi

Bartın Üniversitesi

Marmara Üniversitesi

Düzce Üniversitesi

Gazi Üniversitesi

Muğla Sıtkı Koçman Üniversitesi

İnönü Üniversitesi

Kastamonu Üniversitesi

Abant İzzet Baysal Üniversitesi

Adıyaman Üniversitesi

Dumlupınar Üniversitesi

Konya Üniversitesi

Kocaeli Üniversitesi

Bartın Üniversitesi

Kırıkkale Üniversitesi

Bartın Üniversitesi

Bartın Üniversitesi

Gazi Üniversitesi

İstanbul Aydın Üniversitesi

Dumlupınar Üniversitesi

Gazi Üniversitesi

Ordu Üniversitesi

Adnan Menderes Üniversitesi

Ankara Üniversitesi 
Yrd. Doç. Dr. M. Sani ADIGÜZEL

Yrd. Doç. Dr. Mehmet Diyaddin YAŞAR

Yrd. Doç. Dr. Mehmet UMUZDAŞ

Yrd. Doç. Dr. Metin DENIZ

Yrd. Doç. Dr. Murat GENÇ

Yrd. Doç. Dr. Nail iLHAN

Yrd. Doç. Dr. Nalan OKAN AKIN

Yrd. Doç. Dr. Nuray MAMUR

Yrd. Doç. Dr. Özcan KARAASLAN

Yrd. Doç. Dr. Özge GÜN

Yrd. Doç. Dr. Sedat BALYEMEZ

Yrd. Doç. Dr. Semra KIRANLI GÜNGÖR

Yrd. Doç. Dr. Sibel SADI

Yrd. Doç. Dr. Suad SAKALLI GÜMÜŞ

Yrd. Doç. Dr. Sultan Bilge KARA

Yrd. Doç. Dr. Süleyman AVCI

Yrd. Doç. Dr. Şenel ELALDI

Yrd. Doç. Dr. Şeyda GÜL

Yrd. Doç. Dr. Tolga KABACA

Yrd. Doç. Dr. Tuncay Yavuz ÖZDEMiR

Yrd. Doç. Dr. Yakup DOĞAN

Dr. Hayriye Tuğba ÖZTÜRK
İstanbul Aydın Üniversitesi

Kilis 7 Aralık Üniversitesi

Gaziosmanpaşa Üniversitesi

Bartın Üniversitesi

Düzce Üniversitesi

Kilis 7 Aralık Üniversitesi

Niğde Üniversitesi

Pamukkale Üniversitesi

Marmara Üniversitesi

Bartın Üniversitesi

Bartın Üniversitesi

Eskişehir Osmangazi Üniversitesi

Kafkas Üniversitesi

Mustafa Kemal Üniversitesi

Okan Üniversitesi

Marmara Üniversitesi

Cumhuriyet Üniversitesi

Atatürk Üniversitesi

Pamukkale Üniversitesi

FIrat Üniversitesi

Kilis 7 Aralık Üniversitesi

Ankara Üniversitesi 


\section{IÇINDEKILER / CONTENTS}

\section{Prof. Dr. Firdevs GÜNEŞ}

Konuşma Öğretimi Yaklaşım ve Modelleri

Speech Teaching Approaches and Models

doi number: 10.14686/BUEFAD.201416205

\section{Barış ÇUKURBAŞı - Prof. Dr. Aytekin IŞMAN}

Öğretmen Adaylarının Dijital Yerli Özelliklerinin Incelenmesi (Bartın Üniversitesi Örneği)

Examination of Teacher Candidates' Digital Natives Features (Example of Bartın University)

doi number: 10.14686/BUEFAD.201416206

Yrd. Doç. Dr. Süleyman GÖKSOY - Doç. Dr. Engin ASLANARGUN

Denetim Sürecinde Eğitim Denetmenlerinin Davranışları

Behaviours of Supervisors in the Process of Supervision

$55-77$

doi number: 10.14686/BUEFAD.201416207

Arş. Gör. Yunus ÖZYURT - Doç. Dr. Altay EREN

Fen Bilgisi Öğretmen Adaylarının Öğretmenlik Mesleğine ve Kopya Çekmeye Yönelik Tutumlarının Görünümü

Profiles of Pre-Service Science Teachers' Attitudes towards the Teaching Profession and Cheating doi number: 10.14686/BUEFAD.201416208

\section{Yrd. Doç. Dr. Sefa DÜNDAR}

The Investigation of Spatial Skills of Prospective Teachers with Different Cognitive

Bilissel Stilleri Farklı Ogretmen Adaylarının Uzamsal Becerilerinin Incelenmesi

doi number: 10.14686/BUEFAD.201416209

Yrd. Doç. Dr. Abdulkerim KARADENiz

Eleştirel Okuma Özyeterlilik Algısı Ölçeğinin Geçerlilik ve Güvenirlik Çalışması

Critical Reading Self-Efficacy Perception Scale Validity and Reliability Study

doi number: 10.14686/BUEFAD.201416210

Yrd. Doç. Dr. Ayşen KARAMETE - Öğr. Gör. Hüseyin GÜNEŞ

İlköğretim Seçmeli Satranç Dersi Başlangıç Düzeyi Birinci Basamak Bilgisayar Destekli Öğretim Tasarımı

Primary School First Grade Beginner Level Chess Course Computer-Aided Instructional Design

doi number: 10.14686/BUEFAD.201416211

Doç. Dr. Fahri TEMizYÜREK - Arş. Gör. Arzu ÇEVIK

Mustafa Ruhi Şirin'in Çocuk Edebiyatı Sahasındaki Eserlerinin Dil ve Kavram Bağlamında İncelenmesi

Examination of Mustafa Ruhi Sirin's Works in Field of Children's Literature According to Context of Language

Concept

doi number: 10.14686/BUEFAD.201416212

Dr. Gizem KARAOĞLAN YILMAZ - Dr. Ramazan YILMAZ - Arş. Gör. Barış SEZER

Üniversite Öğrencilerinin Güvenli Bilgi ve İletişim Teknolojisi Kullanım Davranışları ve Bilgi Güvenliği Eğitimine Genel Bir Bakış

Secure Information and Communication Technology Usage Behavior of University Students and an Overview

to Information Security Training

$176-199$

doi number: 10.14686/BUEFAD.201416213 


\section{IÇINDEKILER / CONTENTS}

\section{Yrd. Doç. Dr. Erdal TAŞLIDERE}

Kavramsal Değişim Yaklaşımının Doğru Akım Devreleri Konusundaki Kavram Yanılgılarının Giderilmesine Etkisi

Effect of Conceptual Change Instruction on Remedying Misconceptions Concerning Direct Current Circuits doi number: 10.14686/BUEFAD.201416214

\section{Dr. H. Tuğba ÖzTÜRK}

Küreselleşme ve Ağ Toplumları Odağında Bilgi ve Illetişim Teknolojileri ile Eğitim Education with Information and Communication Technologies in the Scope of Globalisation and Network Society doi number: 10.14686/BUEFAD.201416215

Yrd. Doç. Dr. Serkan TiMUR - Şirin YILMAZ - Yrd. Doç. Dr. Betül TiMUR Fen ve Teknoloji Öğretmenleri İle Öğretmen Adaylarının Fen Deneylerinin Amaçlarını Kavramaya Yönelik Tutumlarının İncelenmesi Investigating Science and Technology Teachers' and Pre-Service Teachers' Attitudes towards Understanding the Objectives of Science Experiments doi number: 10.14686/BUEFAD.201416216

\section{Fazilet Eda YILMAZ - Gülşah TOPALOĞLU - Mustafa AKYÜZLÜER}

Grupla Yapılan Müzik Etkinliğinin Otizmli Çocukların Sosyal Becerilerine Etkisinin Betimlenmesi

Description of the Effect of Musical Activity with Group on Social Skills of Children with Autism doi number: 10.14686/BUEFAD.201416217

Yrd. Doç. Dr. Özcan Erkan AKGÜN - Şirin KÜçÜK

Barış ÇUKURBAŞI - İsmail TONBULOĞLU

Sözel veya Görsel Baskın Öğrenme Stilini Belirleme Ölçeği Türkçe Formunun Geçerlik ve Güvenirlik Çalışması

Validity and Reliability Study of the Visual versus Verbal Style of Processing Scale Turkish Form doi number: 10.14686/BUEFAD.201416218

Arş. Gör. Ruhşen ALDEMiR - Doç. Dr. Enver TATAR Teknoloji Destekli Matematik Eğitimi Hakkında Yayınlanan Makalelerinin İncelenmesi An Analysis of Articles on Technology Assisted Mathematics Education doi number: 10.14686/BUEFAD.201416219

İsmail TONBULOĞLU - Prof. Dr. Aytekin IŞMAN

Öğretmenlerin Sosyal Ağları Kullanım Profillerinin İncelenmesi

Exploring Teachers' Social Network Usage

doi number: 10.14686/BUEFAD.201416220

Arş. Gör. Dr. Osman çiMEN - Prof. Dr. Mehmet YILMAZ Dönüşümsel Öğrenme Kuramına Dayalı Çevre Eğitiminin Biyoloji Öğretmen Adaylarının Çevre Sorunlarına Yönelik Algılarına Etkisi The Influence of Transformative Learning Based Environmental Education on Preservice Biology Teachers' Perception of Environmental Problems doi number: 10.14686/BUEFAD.201416221

Doç. Dr. İ. Halil TÜRKER - Yrd. Doç. Dr. Fatih ÖZDEMiR Resim-İş Eğitimi Programları Grafik Ana Sanat Ders İçerikleri ve İşleniş Biçimleri Course Outlines and Teaching Styles at Graphic Design Lessons at Fine Arts Education Departments doi number: 10.14686/BUEFAD.201416222 


\section{IÇINDEKILER / CONTENTS}

\section{Yrd. Doç. Dr. Süreyya GENÇ}

Sanat Eğitiminde Eğitsel Oyunların Önemi

Importance of Educational Games in Arts Education

doi number: 10.14686/BUEFAD.201416223

Doç. Dr. Lale HÜSEYNOVA

Müzik Öğretmenliği Bölümü Öğrencilerinin Keman Çalma Performanslarını Etkileyen Bazı Değişkenler

Some Variables that Affect the Violin - Playing Performance of Students in the Department of Music Teaching doi number: 10.14686/BUEFAD.201416224

\section{Yrd. Doç. Dr. Vafa SAVAŞKAN}

Eğitim Fakültesi Öğrencilerinin Günlük Tutma Alışkanlıklarının Öğrenci Görüşleri Doğrultusunda İncelenmesi

Investigate the Logging Habits of the Faculty of Education Students in Terms of Students' Opinion doi number: 10.14686/BUEFAD.201416225

Arş. Gör. Melehat GEZER - Prof. Dr. İbrahim Fevzi ŞAHIN

Yrd. Doç. Dr. Meral ÖNER SÜNKÜR - Arş. Gör. Elif MERAL

8. Sınıf Türkiye Cumhuriyeti İnkılâp Tarihi ve Atatürkçülük Dersi Öğretim Programı Kazanımlarının Revize Edilmiş Bloom Taksonomisine Göre Değerlendirilmesi

An Evaluation of the Outcomes of the 8th Grade History of Turkish Revolution and Kemalism Lesson According to Revized Bloom's Taxonomy doi number: 10.14686/BUEFAD.201416226

Prof. Dr. Firdevs GÜNEŞ - Doç. Dr. Coşkun ARSLAN - Arş. Gör. Ayşe ELiÜşÜK Atılganlık Eğitiminin Üniversite Öğrencilerinin Kişiler Arası Problem Çözme, Algılanan Sosyal Destek ve Atılganlık Düzeyleri Üzerine Etkisi 
Bartın Üniversitesi

Eğitim Fakültesi Dergisi

Cilt 3, Sayı 1, s. 176 - 199, Yaz 2014

BARTIN - TÜRIKIYE

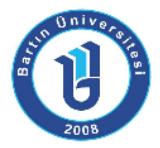

ISSN: 1308-7177
Bartin University

Journal of Faculty of Education

Volume 3, Issue 1, p. 176 - 199, Summer 2014

BARTIN - TURIEY

\title{
Üniversite Öğrencilerinin Güvenli Bilgi ve İletişim Teknolojisi Kullanım Davranışları ve Bilgi Güvenliği Eğitimine Genel Bir Bakış
}

\author{
Dr. Gizem KARAOĞLAN YILMAZ \\ Ankara Üniversitesi \\ Eğitim Bilimleri Fakültesi \\ gkaraoglanyilmaz@gmail.com
}

\author{
Dr. Ramazan YILMAZ \\ Bartın Üniversitesi \\ Meslek Yüksekokulu \\ ramazanyilmaz067@gmail.com
}

\author{
Arş. Gör. Barış SEZER \\ Hacettepe Üniversitesi \\ Tıp Fakültesi \\ barissezer13@hotmail.com
}

Özet: Bilgi ve iletişim teknolojilerinin (BiT) bireysel ve toplumsal hayata sağladığı pek çok faydanın yanında güvenli olmayan BiT kullanımı sonucunda bireyler çeşitli problemlerle karşı karşıya kalabilmektedirler. BiT'in güvenli kullanımı konusunda eğitim sistemine ve eğitimcilere önemli görevler düşmektedir. Bu amaçla Milli Eğitim Bakanlığı (MEB) güncellenen Bilişim Teknolojileri ve Yazılım dersi müfredatında öğrenci ihtiyaçlarına bağlı olarak bilgi güvenliği eğitimlerinin verilmesi gerektiğini önermiştir. Ancak bu konuda öğrenci intiyaçlarını ortaya koyan çalışmaların eksikliği alanyazında hissedilmektedir. Gerçekleştirilen bu çalışmanın amacı, zorunlu eğitim süreçlerinden geçerek üniversiteye yeni başlayan öğrencilerin bilgi güvenliğine yönelik davranış durumlarını ortaya koymaktır. Çalışma üniversite birinci sınıftaki 124 öğrenci üzerinde yürütülmüştür. Araştırmanın verileri nicel ve nitel yöntemler kullanılarak elde edilmiştir. Elde edilen bulgular doğrultusunda öğrenci ihtiyaçlarına bağlı olarak Bilişim Teknolojileri ve Yazılım ders müfredatında yer alması gereken konulara ilişkin öneriler getirilmiştir.

Anahtar Sözcükler: Bilgi Güvenliği, Bilgi Güvenliği Eğitimi, Kullanıcı Davranışları

\section{Secure Information and Communication Technology Usage Behavior of University Students and an Overview to Information Security Training}

\begin{abstract}
Information and communication technologies (ICT) provide many benefits to the individual and social life whereas they can also bring about some unwanted problems as a result of their unsafe use. Educators and the education system itself have responsibilities for the students' safe use of ICT. For this purpose, in the revised version of the curriculum of Information Technology and Software (IT\&S) course, the Ministry of National Education proposed that topics on safe use of ICT should be included in the curriculum based on the needs of the students. However, there is a gap in the literature with regard to the needs of the students. Therefore, the purpose of this research is to examine the behaviour of the first year undergraduate students concerning the information security. First year students as they took a compulsory Information Technology and Software course at the Ministry of National Education schools. The study was conducted on 124 first year students. Data were analyzed using the qualitative and quantitative methods. Drawing on the findings we suggested some emerged topics which could be included in the IT\&S curriculum based on the students' needs.
\end{abstract}

Key Words: Information Security, Information Security Training, User Behavior 


\section{GíRiş}

Bilgi ve iletişim teknolojilerinin (BiT) yaşamın her alanına sağlamış olduğu pek çok faydanın yanında kullanıcılar BiT'in doğru olmayan kullanımından kaynaklanan bir takım problemlerle karşı karşıya kalabilmektedir. Bilgi güvenliğini tehlikeye sokabilecek davranış ve uygulamaların sonucunda karşı karşıya kalınan güven ve gizlilik kaybı, çeşitli siber tehdit ve saldırılar bu problemlerden bazılarıdır. Bu problemler kullanıcılar üzerinde ciddi maddi ve manevi kayıplara yol açabilmektedir. BiT’ten doğru bir şekilde yararlanma sürecinde yöneticilere, eğitimcilere ve ebeveynlere önemli görevler düşmektedir. Bu görevlerden en önemlisi geleceğin anne-babaları olacak olan çocukların ve gençlerin BiT'in doğru ve güvenli kullanımı konusundaki farkındalık düzeylerini artırmaktır.

Hayatımızın her alanına hızla giren yeni teknolojilere yönelik olarak kullanıcı davranışları analiz edildiğinde çoğu kullanıcı davranışının bilgi güvenliği açıklarına sebebiyet verebildiği görülmüştür (Adams ve Sasse, 1999; Besnard ve Arief, 2004; Brostoff ve Sasse, 2001; Maxion ve Reeder, 2005). Güvenliğin en önemli zaafının insan davranışı olduğu bilinmektedir. Wagner ve Brooke'e (2007) göre bilgi güvenliğini oluşturan zincirin en zayıf halkası insan faktörüdür. Schneier (2000), güvenliğin sadece en zayıf halkanın güvenliği kadar olabileceğini ve insanların da bu zincirdeki en zayıf halka olduğunu belirtmiştir. Poulsen (2000) ise bilgisayar güvenliğindeki insan faktörünün gözden kaçırıldığını, kurumların güvenlik duvarları, şifreleme ve güvenli erişim cihazlarına milyonlarca dolar harcadıklarını, ancak bu teknik önlemlerin güvenlik zincirindeki en zayıf halka olan insan faktöründen kaynaklanan tehdit ve açıkları önleyemediği için harcanan paranın boşa gittiğini belirtmektedir. Gonzales ve Sawicka (2002), bilgi güvenliğinin teknoloji ve insanı içerdiğini, güvenlik sistemleri ne kadar iyi tasarlanmış ve uygulanmış olursa olsun yönetim ve kullanımının insanlara bağlı olduğunu ve bilgi sistemlerinde insan faktörünün daha iyi anlaşılması gerektiğini belirtmektedir. Bu çerçeveden bakıldığında bilgi güvenliğinin sağlanmasında teknik altyapının oluşturulması kadar insan faktörünün de dikkate alınması önemlidir.

Bilgi güvenliğini sağlamaya yönelik araştırmaların çoğunun güvenlik yazılımları ve modelleri oluşturma gibi teknik ya da cezai yaklaşımlar oluşturma gibi hukuksal ve idari boyutlu araştırmalar olduğu görülmektedir (Besnard ve Arief, 2004; Egan, 2004; Mahabi, 2010; Markotten, 2002; Vroom ve Solms, 2004). Alanyazında insan faktöründen kaynaklanan bilgi güvenliği hatalarını belirlemeye ve bunları ortadan kaldırmaya yönelik araştırmaların ise yeni yeni gerçekleştirildiği görülmektedir (Kaşıkçı, Çağıltay, Karakuş, Kurşun ve Ogan, 2014; Mart, 
2012). Bilgi güvenliği zincirindeki en zayıf halkanın insan faktörü olduğu göz önüne alındığında, insan faktöründen kaynaklı bilgi güvenliği hata ve ihlallerinin belirlenmesi ve bunların giderilmesine daha çok önem verilmesi gerekmektedir (Colwill, 2009; Jones ve Colwill, 2008). Çok büyük yatırımlarla oluşturulan teknik boyuttaki güvenlik sistemlerini geliştiren, yöneten ve kullananların da insanlar olduğu göz önüne alındığında insan faktörü bilgi güvenliğinin sağlanmasındaki teknik boyutun da ötesine geçmektedir. Bu noktada kurumların ve kullanıcıların bilgi güvenliği tehditleri konusunda eğitilmesi ve farkındalıklarının yükseltilmesi gerekmektedir (Chou, Chan ve Wu, 2007; Wishart, Oades ve Morris, 2007). Söz konusu eğitimlerin verilebilmesi ve bilgi güvenliği ihtiyaçlarının belirlenebilmesi için bireylerin güvenli BiT kullanımı konusunda gösterdikleri davranış durumlarının ortaya konulması gerekir.

Talim ve Terbiye Kurulu Başkanlığı kararına (2012) göre BiT'in yaşamın her alanına hızla girmesine bağlı olarak bundan en uygun şekilde yararlanacak ve BiT'in vereceği olumsuz etkilerden bireyleri koruyacak güncel eğitim programlarına intiyaç duyulmuştur. Bu amaçla BiT'in olumsuz etkilerinden bireyleri korumak amacıyla da yapılandırılacak bilişim teknolojileri eğitim programlarında teknoloji kullanımı ve üretiminde etik değerler, gizlilik, bilgi ve veri güvenliği, siber suçlar, sanal zorbalık, internet bağımlılığı gibi kişisel ve toplumsal açıdan önemli konulara da yer verilmesi gerektiği belirtilmektedir. Rapora göre bilişim teknolojileri ders programlarında "yalnızca ofis otomasyonlarının öğretildiği yapıdan uzaklaşılmalı ve yukarıda belirtilen konularla birlikte yetişen bireylerin yeni teknolojileri kendi kendilerine öğrenebilme ve yeni teknolojilerin doğru kullanımı konusunda kültür geliştirmelerine olanak sağlayan bir yaklaşım benimsenmelidir. Bireyleri bilgi teknolojileri üreticileri haline getirmek ve bu bağlamdaki kültürü onların geliştirmelerini sağlamak yeni eğitim programının en temel hedeflerinden olmalıdır." Söz konusu rapora göre yeniden yapılandırılacak bilişim teknolojileri ders programlarının içeriğinin kazandırılmasında bilişim teknolojileri öğretmenlerine büyük sorumluluklar düşmektedir.

Talim ve Terbiye Kurulu Başkanlığı kararında (2012) önerilen bilişim teknolojileri çerçeve programı kapsamındaki bu konuların öğretilmesinde öğrenci ihtiyaç ve durumlarına göre bilişim teknolojileri öğretmenlerinin eğitim içeriğine yön vermesi gerektiği belirtilmektedir. Ancak önerilen çerçeve programındaki konuların güncel konular olması nedeniyle bu konuların öğretiminde öğretmenlere yol gösterebilecek araştırmalara ihtiyaç duyulmaktadır. Örneğin çerçeve programda yer alan bilgi ve veri güvenliği konusunda öğretmenlerin eğitim içeriğine karar verebilmeleri için öncelikle konuya ilişkin öğrenci 
düzeyinin ve ihtiyaçlarının belirlenmesi gerekir. Aksi halde verilecek olan eğitimin amaçlara ulaşmada yetersiz kalacağı düşünülmektedir. Bu nedenle bilgi güvenliğini sağlama konusunda öğrenci ihtiyaçlarının belirlenerek, ihtiyaçlar doğrultusunda bilgi güvenliği eğitimlerinin verilmesi önem arz etmektedir.

Bilgi güvenliği araştırmalarının ulusal düzeyde yapılmasının önemli olduğu düşünülmektedir. Örneğin gelişmiş ülkelerdeki devlet politikaları çocuk ve gençlerin bilgi güvenliklerini sağlama konusunda bireysel olarak yapılacakların dışında da ciddi teknik ve yasal önlemler aldırabilmektedir. Ancak bu durum ülkeden ülkeye değişebilmektedir. Bu nedenle bilgi güvenliği araştırmalarına ulusal düzeyde bakılması önemlidir. İlgili alanyazın incelemesinde ülkemiz koşullarındaki çocuk ve gençlerin bilgi güvenliklerini sağlama konusunda çeşitli çalışmalar gerçekleştirildiği görülmektedir. Ancak söz konusu araştırmaların bir kısmında bilgi güvenliğinin çocuk ve gençler üzerinde oluşturabileceği olası etkilerden ve bilgi güvenliği eğitiminin öneminden bahsedilirken (Canbek ve Sağıroğlu, 2007; Ceylan, 2013; Çelen, Çelik ve Seferoğlu, 2011; Çubukçu ve Baysan, 2013; Demirel, Yörük ve Özkan, 2012; Ersoy ve Ersoy, 2008; Öğün ve Kaya, 2013; Şahinaslan, Kandemir ve Şahinaslan, 2009; Şahinaslan, Kantürk, Şahinaslan ve Borandağ, 2009; Vural ve Sağıroğlu, 2008), bir kısmında da güvenliğin sağlanabilmesi için gerekli teknik yöntemlerden (Canbek ve Sağıroğlu, 2006; Öğün ve Kaya, 2013; Yavanoğlu, Sağıroğlu ve Çolak, 2012; Zeydan, 2006) ve yasal-idari düzenlemelerden (Ersoy, 2007; Hekim ve Başıüyük, 2013; Koç ve Kaynak, 2010; Tekerek, 2008) bahsedilmektedir. Söz konusu araştırmalarda da belirtildiği üzere çocuk ve gençlerin güvenli BiT kullanım davranış ve ihtiyaç durumlarını saptayarak, söz konusu ihtiyaçların giderilmesine yönelik yeni çalışmalara ihtiyaç duyulmaktadır.

\subsection{Araştırmanın Amacı}

Zorunlu eğitim süreçlerinden geçerek üniversiteye gelen öğrencilerin bilgi güvenliğine ilişkin davranış durumlarını ortaya koymayı amaçlayan bu çalışmadan elde edilen bulgular doğrultusunda MEB'in Bilişim Teknolojileri ve Yazılım dersi müfredatında öğrenci ihtiyaçlarına bağıı olarak hangi konulara yer verilmesi gerektiği konusunda öneriler getirilmiştir.

\section{YÖNTEM}

Araştırmanın bu bölümünde araştırma modeli, çalışma grubu, veri toplama aracı ile verilerin analiz ve yorumlanmasına ilişkin bilgilere yer verilmiştir. 


\subsection{Araştırma Modeli}

Araştırmada nicel ve nitel araştırma yöntemleri kullanılmıştır. Bu çalışma iki aşamada gerçekleştirilmiştir. Araştırmanın ilk aşamasında araştırmacılar tarafından geliştirilen bir anket aracılığıyla öğrencilerin güvenli Biт kullanımına ilişkin davranışlar nicel olarak betimlenmeye çalışıımıştır. Araştırmanın ikinci aşamasında ise nicel olarak betimlenen davranışların derinlemesine analizinin yapılabilmesi için araştırmacılar tarafından geliştirilen öğrenci görüşlerini belirleme formu aracılığıyla elde edilen veriler içerik analizi kullanılarak bulgular özetlenmiştir.

\section{2. Çalışma Grubu}

Araştırmada MEB'in ilk ve ortaöğretim süreçlerinden geçerek üniversiteye başlayan öğrencilerin güvenli BiT kullanım davranışlarının ortaya konulması ve buna bağlı olarak MEB'in ilk ve ortaöğretim Bilişim Teknolojileri ve Yazılım ders müfredatında verilecek olan bilgi güvenliği eğitimlerine yönelik öneriler getirilmesi amaçlanmıştır. Bu nedenle araştırmanın

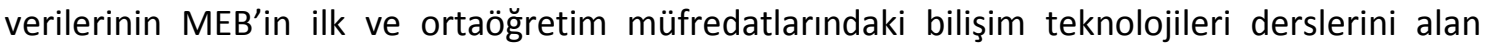
öğrencilerden elde edilmesi önemlidir. Araştırmanın verileri 2012-2013 akademik yılı güz döneminde üniversite birinci sınıfa devam eden 124 öğrenciden elde edilen verilerle sınırlıdır. Söz konusu öğrencilerle yapılan görüşme sonrasında öğrencilerin MEB'in ilk ve ortaöğretim müfredatlarındaki bilişim teknolojileri dersleri dışında bilişim teknolojisiyle ilgili herhangi bir ders ya da kurs almadıkları görülmüştür. Öğrencilerin demografik bilgilerine ilişkin veriler Tablo 1 'de verilmiştir.

Tablo 1: Öğrencilerin Demografik Bilgilerine İlişkin Veriler

\begin{tabular}{cccc}
\hline Değişken & Grup & $\mathbf{N}$ & \% \\
\hline \multirow{2}{*}{ Cinsiyet } & Kadın & 75 & 60.5 \\
& Erkek & 49 & 39.5 \\
\hline \multirow{2}{*}{ Yaş } & $16-20$ & 87 & 70.2 \\
& $21-25$ & 37 & 29.8 \\
\hline Bilgisayar, Tablet ya & Var & 99 & 79.8 \\
da Akıllı Telefona & Yok & 25 & 20.2 \\
Sahip Olma Durumu & Var & 116 & 93.5 \\
Sosyal Ağa Üyeliği & Yok & 8 & 6.5 \\
\hline
\end{tabular}

Tablo 1 incelendiğinde öğrencilerin yaklaşık \%60'ının kadın, \%40'ının da erkek olduğu; yaklaşık \%70'inin 16-20 yaş aralığında, \%30'ununda 21-25 yaş aralığında olduğu görülmektedir. Söz konusu öğrencilerin yaklaşık \%80'i bilgisayara sahip iken, $\% 20$ sinin ise bilgisayara sahip 
olmadığı görülmektedir. Ayrıca öğrencilerin $\% 93.5^{\prime}$ inin sosyal ağlara üye olduğu, \%6.5'inin ise üye olmadığı görülmektedir.

\subsection{Veri Toplama Aracı}

Araştırmada nicel veri toplama aracı olarak bilgi güvenliği farkındalık anketi; nitel veri toplama aracı olarak ise öğrenci görüşlerini belirleme formu kullanılmıştır. Veri toplama araçları araştırmacılar tarafından geliştirilmiştir. Veri toplama araçlarındaki maddeler alanyazın incelemesine bağlı olarak araştırmacılar tarafından hazırlandıktan sonra eğitim teknolojisi alanından üç uzman maddeleri kapsam geçerliliği açısından, bir Türk dili uzmanı da dil ve anlatım açısından incelemiştir. Uzmanların görüşleri doğrultusunda maddeler üzerinde gerekli düzenlemeler yapılarak maddelere son şekli verilmiştir. Anketten elde edilen veriler frekans ve yüzde şeklinde ifade edilerek yorumlanmıştır. Nitel veri analizinde öğrenci görüşlerini belirleme formu aracılığıyla öğrencilerden elde edilen veriler bağımsız iki araştırmacı tarafından kodlanarak alt temalar ortaya konulmaya çalışılmış ve bu alt temalar frekans ve yüzde olarak ifade edilmeye çalışılarak, konuyla ilgili öğrenci görüşlerinden örnekler verilmiştir.

Alanyazın taraması ve uzmanlardan gelen öneriler doğrultusunda yapılan kapsam geçerliliği sonucunda yukarıda açıklanan nicel ve nitel veri toplama araçlarında Biт kullanımı konusunda kullanıcı davranışlarıyla ilgili mevcut durumu belirlemeye yönelik olarak; bilgisayara erişim güvenliği, zararlı programlar ve korunma yolları, sosyal mühendislik, parola güvenliği, dosya erişim ve paylaşım güvenliği, yedekleme yapma, internet ve ağ güvenliği, kablolu ve kablosuz modem güvenliği, e-posta güvenliği konularına ilişkin maddeler yer almaktadır.

\section{BULGULAR}

Araştırmanın bu bölümünde nicel ve nitel veri toplama araçlarından elde edilen bulgulara ilişkin bilgilere yer verilmiştir.

\subsection{Nicel Verilere ilişkin Bulgular}

Gerçekleştirilen nicel analizler doğrultusunda, öğrencilerin antivirüs programı kullanma durumuna ilişkin bulgular Tablo 2'de verilmiştir. 
Üniversite Öğrencilerinin Güvenli Bilgi ve İletișim Teknolojisi Kullanım Davranışları...

F. Gizem KARAOĞLAN YILMAZ - Ramazan YILMAZ - Barış SEZER

Tablo 2: Antivirüs Programı Kullanma Durumuna İlişkin Bulgular

\begin{tabular}{ccc}
\hline Antivirüs Programı Kullanma Durumu & Frekans & Yüzde \\
\hline Kullanıyorum & 105 & 84.7 \\
Kullanmıyorum & 19 & 15.3 \\
Toplam & 124 & 100.0 \\
\hline
\end{tabular}

Tablo 2 incelendiğinde, öğrencilerin \%84.7'si antivirüs programı kullandığını ( $f=105$ ), \%15.3'ü ise antivirüs programı kullanmadığını ( $f=19)$ belirtmektedir.

Gerçekleştirilen nicel analizler doğrultusunda, üniversite öğrencilerinin antivirüs programını ne sıklıkla güncellediğine ilişkin bulgular Tablo 3'te verilmiştir.

Tablo 3: Antivirüs Programını Güncelleme Durumuna iliş̧kin Bulgular

\begin{tabular}{ccc}
\hline Antivirüs Programını Güncelleme Durumu & Frekans & Yüzde \\
\hline Otomatik Güncellerim & 36 & 29.0 \\
Günlük Güncellerim & 5 & 4.0 \\
Haftalık Güncellerim & 20 & 16.1 \\
Aylık Güncellerim & 31 & 25.0 \\
Altı Ayda Bir Güncellerim & 12 & 9.7 \\
Yıllık Güncellerim & 2 & 1.6 \\
Güncelleme Yapmıyorum & 18 & 14.5 \\
Toplam & 124 & 100.0 \\
\hline
\end{tabular}

Tablo 3 incelendiğinde antivirüs programını, öğrencilerin \%29.0'u otomatik olarak güncellediğini ( $f=36), \% 4.0^{\prime}$ ü günlük $(f=5), \% 16.1^{\prime} i$ haftalık $(f=20), \% 25.0^{\prime} i$ aylık $(f=31), \% 9.7$ si altı ayda bir ( $f=12), \% 1.6$ 'sı yıllık ( $f=2)$ güncellediğini belirtmekte olup \%14.5'i ise güncelleme yapmadıklarını $(f=18)$ ifade etmiştir.

Gerçekleştirilen nicel analizler doğrultusunda, öğrencilerin girdikleri web sitesi veya kullandıkları programın güvenli olup olmadığına dikkat etme durumuna ilişkin bulgular Tablo 4'te verilmiştir.

Tablo 4: Girilen Web Sitesi veya Kullanılan Programın Güvenli Olup Olmadığına Dikkat Etme Durumuna iliş̧kin Bulgular

\begin{tabular}{ccc}
\hline $\begin{array}{c}\text { Web Sitesi veya Programın Güvenli Olup } \\
\text { Olmadığına Dikkat Etme Durumu }\end{array}$ & Frekans & Yüzde \\
\hline Dikkat Ederim & 63 & 50.8 \\
Dikkat Etmem & 61 & 49.2 \\
Toplam & $\mathbf{1 2 4}$ & $\mathbf{1 0 0 . 0}$ \\
\hline
\end{tabular}


Tablo 4 incelendiğinde girdikleri web sitesi veya kullandıkları programın güvenli olup olmadığına, öğrencilerin \%50.8'i dikkat ettiğini ( $f=63), \% 49.2^{\prime}$ si ise dikkat etmediğini ( $f=61$ ) belirtmektedir. Bu sonuçlara göre öğrencilerin yaklaşık yarısının girdikleri web sitesinin ya da kullandıkları programın güvenli olup olmadığına yeterince dikkat etmediği görülmektedir.

Gerçekleştirilen nicel analizler doğrultusunda, öğrencilerin korsan yazılım kullanma durumuna ilişkin bulgular Tablo 5'te verilmiştir.

Tablo 5: Korsan Yazılım Kullanma Durumuna ilişskin Bulgular

\begin{tabular}{ccc}
\hline Korsan Yazılım Kullanma Durumu & Frekans & Yüzde \\
\hline Kullanıyorum & 48 & 38.7 \\
Kullanmıyorum & 76 & 61.3 \\
Toplam & 124 & 100.0 \\
\hline
\end{tabular}

Tablo 5 incelendiğinde öğrencilerin \%38.7'si korsan yazılım kullandığını ( $f=48$ ), \%61.3'ü ise kullanmadığını ( $f=76$ ) belirtmektedir. Bu sonuçlara göre öğrencilerin \%38.7'si korsan yazılım kullanımından kaynaklanabilecek tehditlere açık olduğu görülmektedir.

Gerçekleştirilen nicel analizler doğrultusunda, öğrencilerin bilgisayar ortamındaki verileri ne sıklıkla yedeklediklerine ilişkin bulgular Tablo 6'da verilmiştir.

Tablo 6: Yedekleme Yapma Durumuna İlişkin Bulgular

\begin{tabular}{ccc}
\hline Yedekleme Yapma Durumu & Frekans & Yüzde \\
\hline Günlük & 7 & 5.6 \\
Haftalık & 10 & 8.1 \\
Aylık & 40 & 32.3 \\
Altı Ayda Bir & 23 & 18.5 \\
Yıllık & 12 & 9.7 \\
Yedekleme Yapmıyorum & 32 & 25.8 \\
Toplam & $\mathbf{1 2 4}$ & $\mathbf{1 0 0 . 0}$ \\
\hline
\end{tabular}

Tablo 6 incelendiğinde öğrencilerin \%5.6'sı verilerini günlük ( $f=7)$, \%8.1'i haftalık ( $f=10)$, \%32.3'ü aylık ( $f=40), \% 18.5^{\prime} i$ altı ayda bir ( $\left.f=23\right), \% 9.7$ 'si yıllık ( $f=12$ ) güncellediğini belirtmekte olup $\% 25.8^{\prime} i$ ise yedekleme yapmadıklarını $(f=32)$ ifade etmiştir. Öğrencilere yedekleme yaparken tercih ettikleri ortam sorulduğunda ise yedekleme yapan öğrencilerin $\% 56.5$ 'i usb belleği, \%13.72'si aynı bilgisayarı, \%13.7'si taşınabilir diskleri (hard disk), \%11.3'ü cd/dvd'yi, \%2.4'ü başka bilgisayarı, \%1.6'sı web ortamını, \%0.8'i ise diğer ortamları tercih ettiklerini belirtmiştir. Bu bulgudan hareketle öğrencilerin yarısından fazlası usb belleği yedekleme için 
tercih ettikleri görülmektedir. Ancak usb belleklerin zararlı program bulaşma olasıllğı en yüksek olan ortamlardan biri olması nedeniyle bu ortamlarda yapılan yedeklemelerin zarar görebileceği düşünülmektedir. Bu nedenle öğrencilerin yedekleme yapılacak ortamlar konusunda bilinçlendirilmesi önemlidir.

Gerçekleştirilen nicel analizler doğrultusunda, öğrencilerin bilgisayarlarındaki dosyaları internette paylaşıma açma durumuna ilişkin bulgular Tablo 7'de verilmiştir.

Tablo 7: Bilgisayardaki Dosyaları İnternette Paylaşıma Açma Durumuna ilişkin Bulgular

\begin{tabular}{ccc}
\hline $\begin{array}{c}\text { Bilgisayardaki Dosyaları Internette } \\
\text { Paylaşıma Açma Durumu }\end{array}$ & Frekans & Yüzde \\
\hline Paylaşıma Açıyorum & 26 & 20.9 \\
Paylaşıma Açmıyorum & 98 & 79.0 \\
Toplam & 124 & 100.0 \\
\hline
\end{tabular}

Tablo 7 incelendiğinde öğrencilerin \%20.9’u bilgisayarlarındaki dosyaları paylaşıma açtığını ( $f=26)$, \%79.0'u ise paylaşıma açmadığını ( $f=98$ ) belirtmektedir. Bu sonuçlar yaklaşık olarak öğrencilerin \%21'inin dosya paylaşımından kaynaklanabilecek bilgi güvenliği tehditleriyle karşı karşıya kalabileceklerini göstermektedir.

Gerçekleştirilen nicel analizler doğrultusunda, öğrencilerin internetten video, müzik, film gibi dosya veya programları yasal siteler dışındaki sitelerden indirme durumuna ilişkin bulgular Tablo 8'de verilmiştir.

Tablo 8: İnternetten Video, Müzik, Film gibi Dosya veya Programları Yasal Siteler Dışındaki Sitelerden İndirme Durumuna İlişkin Bulgular

\begin{tabular}{ccc}
\hline $\begin{array}{c}\text { Internetten Video, Müzik, Film gibi } \\
\text { Dosya veya Programları Yasal Siteler } \\
\text { Dışındaki Sitelerden Indirme Durumu }\end{array}$ & Frekans & Yüzde \\
\hline Indiriyorum & 103 & 83.1 \\
Indirmiyorum & 21 & 16.9 \\
Toplam & $\mathbf{1 2 4}$ & $\mathbf{1 0 0 . 0}$ \\
\hline
\end{tabular}

Tablo 8 incelendiğinde internetten video, müzik, film gibi dosya veya programları yasal siteler dışındaki sitelerden indirme durumuyla ilgili olarak, öğrencilerin \%83.1'i indirdiğini $(f=103), \% 16.9^{\prime} u$ ise indirmediğini ( $f=21$ ) belirtmektedir.

Gerçekleştirilen nicel analizler doğrultusunda, öğrencilerin şifre gerektiren işlemlerde aynı şifreyi kullanma durumuna ilişkin bulgular Tablo 9'da verilmiştir. 
Üniversite Öğrencilerinin Güvenli Bilgi ve İletișim Teknolojisi Kullanım Davranışları...

F. Gizem KARAOĞLAN YILMAZ - Ramazan YILMAZ - Barış SEZER

Tablo 9: Şifre Gerektiren İşlemlerde Aynı Şifreyi Kullanma Durumuna ilişkin Bulgular

\begin{tabular}{ccc}
\hline $\begin{array}{c}\text { Şifre Gerektiren İşlemlerde Aynı } \\
\text { Şifreyi Kullanma Durumu }\end{array}$ & Frekans & Yüzde \\
\hline Aynı Şifreyi Kullanırım & 67 & 54 \\
Aynı Şifreyi Kullanmam & 57 & 46.0 \\
Toplam & 124 & 100.0 \\
\hline
\end{tabular}

Tablo 9 incelendiğinde öğrencilerin \%54'ü şifre gerektiren işlemlerde aynı şifreyi kullandığını ( $f=67)$, \%46.0'sı ise aynı şifreyi kullanmadığını ( $f=57$ ) belirtmektedir. Bu sonuçlara göre öğrencilerin aynı şifre kullanımından kaynaklanabilecek bilgi güvenliği tehditleriyle karşı karşıya kalabileceklerini göstermektedir.

Gerçekleştirilen nicel analizler doğrultusunda, öğrencilerin internet kafe, okul, alışveriş merkezi gibi ortak kullanım alanlarında internetten alışveriş yapma durumuna ilişkin bulgular Tablo $10^{\prime}$ da verilmiştir.

Tablo 10: Ortak Kullanım Alanlarında İnternetten Alışveriş Yapma Durumuna iliş̧kin Bulgular

\begin{tabular}{ccc}
\hline $\begin{array}{c}\text { Ortak Kullanım Alanlarında } \\
\text { Internetten Alışveriş Yapma Durumu }\end{array}$ & Frekans & Yüzde \\
\hline Alışveriş Yaparım & 36 & 29.0 \\
Alışveriş Yapmam & 88 & 71.0 \\
Toplam & 124 & $\mathbf{1 0 0 . 0}$ \\
\hline
\end{tabular}

Tablo 10 incelendiğinde öğrencilerin \%29'u internet kafe, okul gibi ortak kullanım alanlarında internetten alışveriş yaptığını $(f=36), \% 71.0$ 'i ise yapmadığını $(f=88)$ belirtmektedir. Bu sonuçlar öğrencilerin \%29'unun ortak kullanım alanlarından alışveriş yapmaktan kaynaklanabilecek bilgi güvenliği tehditleriyle karşı karşıya kalabileceklerini göstermektedir.

Gerçekleştirilen nicel analizler doğrultusunda, öğrencilerin internete erişim yerlerine ilişkin bulgular Tablo 11'de verilmiştir.

Tablo 11: Öğrencilerin İnternete Erişim Yerlerine İlişkin Bulgular

\begin{tabular}{cc}
\hline Internete Erişim Yerleri & Frekans \\
\hline Ev & 96 \\
Internet Kafe & 21 \\
Arkadaşımdan/Komşumdan & 15 \\
Okul & 46 \\
\hline
\end{tabular}


Tablo 11 incelendiğinde üniversite öğrencilerinin büyük çoğunluğu internete evden $(f=96)$ erişirken bunu sırasıyla internet kafe $(f=21)$, arkadaşımdan/komşumdan $(f=15)$ ve okuldan/işyerinden $(f=46)$ seçenekleri takip etmektedir. Bu sonuçlar öğrencilerin ortak kullanım alanlarında internet kullanımından kaynaklanabilecek bilgi güvenliği tehditleriyle karşı karşıya kalabileceklerini göstermektedir. Örneğin okul gibi ortamlarda bilgisayarın çoğunluğunda güvenliği sağlamak adına antivirüs programları olmasına rağmen antivirüs programlarının güncellenmemesi gibi nedenlere bağlı olarak özellikle taşınabilir depolama aygıtları üzerinden zararlı programlar bulaşabilmektedir.

\subsection{Nitel Verilere ilişkin Bulgular}

Bilgisayara başkalarının erişimini engellemek adına öğrencilerin aldıkları önlemlerle ilgili belirtilen görüşler doğrultusunda yapılan nitel veri analizi sonucu ortaya çıkan alt temalar Tablo 12'de gösterilmektedir.

Tablo 12: Bilgisayara Başkalarının Erişimini Engellemek Adına Öğrencilerin Aldıkları Önlemlere İlişkin Nitel Analiz Sonuçları

\begin{tabular}{llc}
\hline Alt Temalar & $\mathbf{f}$ & $\%$ \\
\hline Kullanıcı adı ve parola kullanma & 87 & 50.3 \\
\hline Güvenlik duvarı kullanma & 17 & 9.8 \\
\hline Antivirüs programı kullanma & 10 & 5.8 \\
\hline Dosyalara şifre koyma & 10 & 5.8 \\
\hline Önlem almıyorum & 8 & 4.6 \\
\hline Bilgisayarın başından kalkınca oturumu şifre ile kapatma & 8 & 4.6 \\
\hline Önlem almadan dosyaları paylaşıma açmama & 7 & 4.0 \\
\hline Güvenlik yazılımlarını güncelleme & 6 & 3.5 \\
\hline Modeme kullanıcı adı ve parola koyma & 5 & 2.9 \\
\hline İnternetten gelen ve kaynağı bilinmeyen tekliflere yanıt vermeme & 2.9 \\
\hline Bilgisayarın fiziksel güvenliğini sağlama & 5 & 1.7 \\
\hline Başkalarına ait taşınabilir depolama aygıtlarını bilgisayara takmama & 3 & 1.2 \\
\hline Bilgisayarı başkalarıyla ortak kullanmama & 2 & 1.2 \\
\hline BıOS’a kullanıcı adı ve şifre koyma & 2 & 0.6 \\
\hline Parmak izi ile giriş yapma & 1 & 0.6 \\
\hline Kablosuz ağları ve ortak ağları kullanmama & 1 & 0.6 \\
\hline Toplam & 1 & $\mathbf{1 0 0}$ \\
\hline
\end{tabular}

Tablo 12 incelendiğinde kullanmış oldukları bilgisayara başkalarının erişimini engellemek adına öğrencilerin aldıkları önlemlere ilişkin öğrencilerin \%50.3'ü “Kullanıcı adı ve parola koyma" ( $f=87$ ), \%9.8'i "Güvenlik duvarı kullanma" ( $f=17), \% 5.8$ ' $\mathrm{f}$ "Antivirüs programı kullanma" ( $f=10), \% 5.8$ ' $i$ "Dosyalara şifre koyma" ( $f=10$ ) şeklinde yanıt vermektedir. Yanıtlar incelendiğinde kullanıcı adı ve parola, güvenlik duvarı kullanımının erişimleri engellemede işe 
yarayabileceği ancak tek başına yeterli olmayacağı düşünülmektedir. Örneğin öğrencilerin \%1.2'si "Bilgisayarı başkalarıyla ortak kullanmama" şeklinde yanıt vermektedir. Her ne kadar güvenlik duvarı aktif hale getirilse de eğer bilgisayar başkalarıyla ortak kullanılıyorsa dışarıdan erişimlere açık olunmaktadır. Öğrencilerin bu konuya dair görüş ve değerlendirmelerinden bazıları şu şekildedir:

"Güvenlik duvarı ayarları mı zaman zaman kontrol ediyorum. Tanımadığım kişilerden gelen e-postaları açmıyorum."

"Bilgisayarda erişilmesi gereken bir şey olmadığı için herhangi bir önlem almıyorum."

Parola güvenliğini sağlamak adına öğrencilerin aldıkları önlemlerle ilgili belirtilen görüşler doğrultusunda yapılan nitel veri analizi sonucu ortaya çıkan alt temalar Tablo 13 'te gösterilmektedir.

Tablo 13: Parola Güvenliğini Sağlamak Adına Öğrencilerin Aldıkları Önlemlere İlişkin Nitel Analiz Sonuçları

\begin{tabular}{lcc}
\hline Alt Temalar & $\mathbf{f}$ & \% \\
\hline Kolay tahmin edilecek şifreler yerine uzun ve karışık şifreler oluşturma & 47 & 34.1 \\
\hline Şifreyi başkalarıyla paylaşmama & 26 & 18.8 \\
\hline Harf, rakam ve özel karakter içeren şifreler kullanma & 23 & 16.7 \\
\hline Şifreyi zaman zaman güncelleme & 14 & 10.1 \\
\hline Aynı şifreyi farklı ortamlarda kullanmama & 9 & 6.5 \\
\hline En az sekiz karakterden oluşan şifre kullanma & 5 & 3.6 \\
\hline Şifre oluştururken deyim gibi kalıp ifadelere şifrede yer vermeme & 4 & 2.9 \\
\hline $\begin{array}{l}\text { Şifre oluştururken ad, soyad, doğum tarihi, doğum yeri kişisel bilgilere şifrede } \\
\text { yer vermeme }\end{array}$ & 2 & 1.4 \\
\hline $\begin{array}{l}\text { Şifreyi ajanda gibi bir yerlere kaydetmeme } \\
\text { Akılda kalıcı parolalar kullanma }\end{array}$ & 2 & 1.4 \\
\hline $\begin{array}{l}\text { Başka bilgisayarlardan mümkün olduğunca kullanıcı adı ve şifre gerektiren } \\
\text { işlemleri yapmama }\end{array}$ & 2 & 1.4 \\
\hline $\begin{array}{l}\text { Şifre oluşturmada klavyede ya da sistematik olarak art arda gelen harf ya da } \\
\text { rakamlara yer vermeme }\end{array}$ & 2 & 1.4 \\
\hline Toplam & $\mathbf{2}$ & $\mathbf{1 3 8}$ \\
\hline
\end{tabular}

Tablo 13 incelendiğinde parola güvenliğini sağlamak adına öğrencilerin aldıkları önlemlere ilişkin öğrencilerin \%34.1'i "Kolay tahmin edilecek şifreler yerine uzun ve karışık şifreler oluşturma" ( $f=47$ ), \%18.8'i "Şifreyi başkalarıyla paylaşmama" ( $f=26), \% 16.7$ 'si "Harf, rakam ve özel karakter içeren şifreler kullanma" $(f=23), \% 10.1$ 'i "Şifreyi zaman zaman güncelleme" ( $f=14)$ şeklinde görüş bildirmektedir. Örneğin çok az öğrencinin parola oluşturmada "Şifre oluşturmada klavyede ya da sistematik olarak art arda gelen harf ya da rakamlara yer vermeme" ( $f=2, \% 1.4)$ şeklinde davranış gösterdiği görülmektedir. Bunun da konuyla ilgili bilgi ve farkındalık eksikliğinden kaynaklanabileceği düşünülmektedir. Öğrencilerin bu konuya dair görüş ve değerlendirmelerinden bazıları şu şekildedir: 
Üniversite Öğrencilerinin Güvenli Bilgi ve İletişim Teknolojisi Kullanım Davranışları...

F. Gizem KARAOĞLAN YILMAZ - Ramazan YILMAZ - Barış SEZER

"Parolamı sayılardan ve rakamlardan oluşturuyorum. Parolamı hatırla gibi seçeneklerden uzak duruyorum."

"internet ve bilgisayarı benden başkası kullanmadığı için özel bir önlem almıyorum."

Internet ortamında dosya paylaşımı yaparken bilgi güvenliğini sağlamak adına öğrencilerin aldıkları önlemlerle ilgili belirtilen görüşler doğrultusunda yapılan nitel veri analizi sonucu ortaya çıkan alt temalar Tablo 14'te gösterilmektedir.

Tablo 14: İnternet Ortamında Dosya Paylaşımı Yaparken Bilgi Güvenliğini Sağlamak Adına Öğrencilerin Aldıkları Önlemlere Illişkin Nitel Analiz Sonuçları

\begin{tabular}{lcc}
\hline Alt Temalar & $\mathbf{f}$ & $\mathbf{\%}$ \\
\hline $\begin{array}{l}\text { Dosyanın/dosyaların paylaştığım kişiler dışında başkaları tarafından görünüp } \\
\text { görünmediğine dikkat etme }\end{array}$ & 30 & 27.0 \\
\hline Internet ortamında dosya paylaşımı yapmama & 20 & 18.0 \\
\hline Paylaşacağım/paylaşılan dosyanın virüslü olup olmadı̆̆ına dikkat etme & 19 & 17.1 \\
\hline Dosya paylaşımında aldığım herhangi bir güvenlik önlemi yoktur & 16 & 14.4 \\
\hline Paylaşım yapılan sitenin/ortamın güvenli olup olmadığına dikkat etme & 14 & 12.6 \\
\hline Paylaşılan dosyaların kişisel bilgileri içerip içermemesine dikkat etme & 4 & 3.6 \\
\hline Dosya paylaşımı yaparken paylaşılan dosyanın şifrelenmesine dikkat etme & 4 & 3.6 \\
\hline Paylaşılacak dosyaları ayrı bir klasör altında toplayarak paylaşma & 2 & 1.8 \\
\hline Kaynağı bilinmeyen dosyaları açmama & 1 & 0.9 \\
\hline Paylaşılan dosyaların yedeklenmesine dikkat etme & 1 & 0.9 \\
\hline Toplam & $\mathbf{1 1 1}$ & $\mathbf{1 0 0}$ \\
\hline
\end{tabular}

Tablo 14 incelendiğinde internet ortamında dosya paylaşımı yaparken bilgi güvenliğini sağlamak adına alınan önlemlere ilişkin öğrencilerin \%27.0'ı “Dosyanın/dosyaların paylaştı̆̆ım kişiler dışında başkaları tarafından görünüp görünmediğine dikkat etme" ( $f=30), \% 18.0$ 'ı "Internet ortamında dosya paylaşımı yapmama" ( $f=20)$, \%17.1'i "Paylaşacağım/paylaşılan dosyanın virüslü olup olmadığına dikkat etme" (f=19), \%14.4'ü "Dosya paylaşımında aldığım herhangi bir güvenlik önlemi yoktur" ( $f=16)$ şeklinde görüş bildirmektedir. Örneğin öğrencilerin bazıları dosya paylaşımında "Paylaşılacak dosyaları ayrı bir klasör altında toplayarak paylaşma" ( $f=2, \% 1.8$ ) şeklinde yanıt vermektedir. Bu durum dosya paylaşımını kolaylaştırması açısından kullanışlı olsa da güvenliği sağlamaya doğrudan bir katkısının olmadığı düşünülmektedir. Bu durumda yine kullanıcı bilgi ve farkındalık durumuna dikkat çekmektedir. Öğrencilerin bu konuya dair görüş ve değerlendirmelerinden bazıları şu şekildedir:

"Paylaşımlarımın kendi arkadaşlarım dışındaki kişilerin görmesini engelliyorum."

"Fazla dosya paylaşımı yapmıyorum, güvenlik için ne yapılması gerekiyor tam olarak bilmiyorum."

Zararlı programlardan korunmak adına öğrencilerin aldıkları önlemlerle ilgili belirtilen görüşler doğrultusunda yapılan nitel veri analizi sonucu ortaya çıkan alt temalar Tablo 15 'te gösterilmektedir. 
Üniversite Öğrencilerinin Güvenli Bilgi ve İletişim Teknolojisi Kullanım Davranışları...

F. Gizem KARAOĞLAN YILMAZ - Ramazan YILMAZ - Barış SEZER

Tablo 15: Zararlı Programlardan Korunmak Adına Öğrencilerin Aldıkları Önlemlere i̇lişkin Nitel Analiz Sonuçları

\begin{tabular}{lcc}
\hline Alt Temalar & $\mathbf{f}$ & $\mathbf{\%}$ \\
\hline Antivirüs programı kullanma & 76 & 38.2 \\
\hline Antivirüs programını güncelleme & 32 & 16.1 \\
\hline Güvenlik duvarını aktif kılma & 23 & 11.6 \\
\hline Bilinmeyen web sitelerine girmeme & 14 & 7.0 \\
\hline Kaynağı bilinmeyen dosyaları açmama & 9 & 4.5 \\
\hline E-posta içeriklerinin güvenli olup olmadığına dikkat etme & 8 & 4.0 \\
\hline Reklam içerikli web sitelerine tıklamama & 8 & 4.0 \\
\hline Güvenli şifre kullanımına dikkat etme & 6 & 3.0 \\
\hline Başkalarına ait taşınabilir aygıtları bilgisayara takmama & 6 & 3.0 \\
\hline Korsan yazılım/program vb. kullanmama & 6 & 3.0 \\
\hline Herhangi bir önlem almıyorum & 6 & 3.0 \\
\hline Dosyaları bilgisayarda açmadan önce güvenlik taraması yapma & 3 & 1.5 \\
\hline Yedekleme yapma & 1 & 0.5 \\
\hline Güvenli dosya paylaşımlarına dikkat etme & 1 & 0.5 \\
\hline Toplam & 199 & $\mathbf{1 0 0}$ \\
\hline
\end{tabular}

Tablo 15 incelendiğinde zararlı programlardan korunmak adına öğrencilerin aldıkları önlemlere ilişkin öğrencilerin \%38.2'si “Antivirüs programı kullanma” ( $f=76), \% 16.1$ 'i “Antivirüs programını güncelleme" ( $f=32), \% 11.6$ 'sı “Güvenlik duvarını aktif kılma" ( $f=23), \% 7$ 'si "Bilinmeyen web sitelerine girmeme" ( $f=14)$ şeklinde ifade etmektedir. Örneğin çok az öğrenci zararlı programlardan korunmak adına "Korsan yazılım/program vb. kullanmama" ( $f=6, \% 3)$ şeklinde yanıt vermiştir. Zararlı programlardan korunmak adına antivirüs kullanımı gibi çeşitli önlemler alınsa da eğer bilgisayar ya da mobil aygıtta kullanılan yazılım korsan ise yine bilgi güvenliği açıkları olabilecektir. Bu nedenle bu konularda öğrenci bilgi ve farkındalı̆ııın artırılması önemlidir. Öğrencilerin bu konuya dair görüş ve değerlendirmelerinden bazıları şu şekildedir:

"Antivirüs programı kullanıyorum ve güvenmediğim dosya ve sitelere girmemeye özen gösteriyorum."

"Istesek de istemesek de bunlar bir şekilde bize ulaşan şeyler ve yeri geldiğinde antivirüs programı bile bunları yakalayamıyor o yüzden çok fazla önlem almıyorum. Gerekli gördügümde antivirüs programılla müdahale ediyorum o kadar."

E-posta güvenliğini sağlamak adına öğrencilerin aldıkları önlemlerle ilgili belirtilen görüşler doğrultusunda yapılan nitel veri analizi sonucu ortaya çıkan alt temalar Tablo 16 'da gösterilmektedir. 
Üniversite Öğrencilerinin Güvenli Bilgi ve İletişim Teknolojisi Kullanım Davranışları...

F. Gizem KARAOĞLAN YILMAZ - Ramazan YILMAZ - Barış SEZER

\section{Tablo 16: E-Posta Güvenliğini Sağlamak Adına Öğrencilerin Aldıkları Önlemlere ilişkin Nitel Analiz Sonuçları}

\begin{tabular}{lcc}
\hline Alt Temalar & $\mathbf{f}$ & $\mathbf{\%}$ \\
\hline Kaynağı bilinmeyen e-postaları açmadan silme & 52 & 39.1 \\
\hline Güvenli şifre kullanma & 28 & 21.1 \\
\hline Tanımadıkları kişilerden gelen e-postalara yanıt vermeme & 10 & 7.5 \\
\hline İstenmeyen e-postaları açmama & 9 & 6.8 \\
\hline Şifre kullanımı dışında bir şeye dikkat etmeme & 7 & 5.3 \\
\hline E-posta şifresini zaman zaman güncelleme & 6 & 4.5 \\
\hline E-posta adresini tanımadıkları kişilerle paylaşmama & 6 & 4.5 \\
\hline Antivirüs programı kullanma & 5 & 3,8 \\
\hline E-posta ile kişisel bilgileri paylaşmama & 3 & 2.3 \\
\hline E-postaları gruplandırmaya/filtreleme dikkat etme & 2 & 1.5 \\
\hline Karşı tarafın iletişim bilgilerinin e-postada olup olmadığına dikkat etme & 2 & 1.5 \\
\hline Önemli işlerde e-postayı kullanmama & 1 & 0.8 \\
\hline Halka açık yerlerde kablosuz ağ üzerinden e-posta hesabına giriş yapmama & 1 & 0.8 \\
\hline Şüpheli gördükleri e-postalarda teyit amaçlı karşı tarafı telefonla arama & 1 & 0.8 \\
\hline Toplam & 133 & 100 \\
\hline
\end{tabular}

Tablo 16 incelendiğinde e-posta güvenliğini sağlamak adına öğrencilerin aldıkları önlemlere ilişkin öğrencilerin \%39.1'i "Kaynağı bilinmeyen e-postaları açmadan silme" ( $f=52)$, \%21.1' $i$ "Güvenli şifre kullanma" ( $f=28$ ), \%7.5' $i$ “Tanımadığım kişilerden gelen e-postalara yanıt vermeme" ( $f=10), \% 6.8$ ' $i$ "istenmeyen e-postaları açmama" $(f=9)$ şeklinde ifade etmektedir. Örneğin çok az öğrenci "E-posta ile kişisel bilgileri paylaşmam" ( $f=3, \% 2.3$ ) şeklinde yanıt vermiştir. Her ne kadar güvenli şifre kullanımı, antivirüs programı kullanımı gibi önlemlere dikkat edilse de eğer e-postada kişisel bilgiler paylaşılıyorsa söz konusu kişiler sosyal mühendislik saldırılarına maruz kalabilirler. Bu konularda da öğrenci bilgi ve farkındalığının artırılması yararlı olacaktır. Öğrencilerin bu konuya dair görüş ve değerlendirmelerinden bazıları şu şekildedir:

"Tanımadığım ve şüphelendiğim kişilerden gelen e-postaları derhal spam olarak işaretliyorum ve engelliyorum."

"Şifre kullanımı dışında bu konuda şimdiye kadar hiçbir şeye dikkat etmedim."

Kablolu ve kablosuz ağ güvenliğini sağlamak adına öğrencilerin aldıkları önlemlerle ilgili belirtilen görüşler doğrultusunda yapılan nitel veri analizi sonucu ortaya çıkan alt temalar Tablo 17 'de gösterilmektedir. 
Tablo 17: Kablolu ve Kablosuz Ağ Güvenliğini Sağlamak Adına Öğrencilerin Aldıkları Önlemlere İlişkin Nitel Analiz Sonuçları

\begin{tabular}{lcc}
\hline Alt Temalar & $\mathbf{f}$ & $\mathbf{\%}$ \\
\hline Modem şifresini tanımadık kişiler ile paylaşmama & 42 & 50.6 \\
\hline Kullandıktan sonra modemi kapatma & 8 & 9.6 \\
\hline Herhangi bir önlem almam & 8 & 9.6 \\
\hline Modemin alınışında gelen arayüz şifresini değiştirme & 7 & 8.4 \\
\hline Tahmin edilmesi zor şifreler oluşturma & 7 & 8.4 \\
\hline Modem şifresini zaman zaman güncelleme & 5 & 6.0 \\
\hline Modemi ve kablosuz ağı başkalarılyla ortak kullanıma açmama & 4 & 4.8 \\
\hline Modemde kullanılmayan portları kapatma & 2 & 2.4 \\
\hline Toplam & $\mathbf{8 3}$ & $\mathbf{1 0 0}$ \\
\hline
\end{tabular}

Tablo 17 incelendiğinde kablolu ve kablosuz ağ güvenliğini sağlamak adına öğrencilerin aldıkları önlemlere ilişkin öğrencilerin \%50.6'sı “Modem şifresini tanımadıklarımla paylaşmama" ( $f=42$ ), \%9.6'sı "Kullandıktan sonra modemi kapatma" ( $f=8), \% 9.6$ 'sı "Herhangi bir önlem almam" ( $f=8), \% 8.4$ 'ü "Modemin alınışında gelen arayüz şifresini değiştirme" ve "Tahmin edilmesi zor şifreler oluşturma" ( $f=7)$ şeklinde ifade etmektedir. Örneğin çok az öğrenci "Modemde kullanmadığım portları kapatma" ( $f=2, \% 2.4)$ şeklinde yanıt vermiştir. Bu durumun doğrudan konu hakkında bilgi sahibi olma ile ilişkisi olduğu düşünülmektedir. Her ne kadar modem şifresini zaman zaman güncelleme gibi önlemlere dikkat edilse de modemdeki kullanılmayan portlar kapatılmadığı sürece kullanıcılar bu açıklıklardan dolayı bilgi güvenliği tehditleriyle karşı karşıya kalabilirler. Bu konularda da öğrenci bilgi ve farkındalığının artırıması yararlı olacaktır. Öğrencilerin bu konuya dair görüş ve değerlendirmelerinden bazıları şu şekildedir:

"Kablosuz ağ güvenlik şifremi kimseyle paylaşmıyorum. Evime gelen eşim dostum cep ten internete girmek isterse şifremi vermek zorunda kalırsam da kimseyle paylaşmaması konusunda uyarıyorum. Çok yayıldığını düşünürsem de değiştirebiliyorum."

"Modemimi kullanmadığım zaman kapalı tutmaya ve modem şifremi kimseyle paylaşmamaya dikkat ediyorum."

Nicel ve nitel veri analizi sonuçları genel olarak değerlendirildiğinde öğrencilerin bilgi güvenliğini sağlama konusunda temel düzeyde güvenlik önlemi aldığı anlaşılmaktadır. Örneğin çoğu öğrenci zararlı programlardan korunmak için antivirüs programı kullanımının yeterli olduğunu düşünmekte ve ek önlemler almamakta ya da bu ek önlemleri bilmemektedir. Analiz sonuçlarına dayalı olarak yine öğrencilerin güvenlik konusunda bir takım yanlış bilgilere de sahip olduğu görülmektedir. Örneğin öğrencilerin bir kısmı tanımadıkları kişilerden gelen epostaları istenmeyen e-posta olarak düşünmekte ve bu e-postaları okumadan silmektedirler. 


\section{TARTIŞMA VE SONUÇ}

Yükseköğretim programlarında öğrenim gören öğrencilerin güvenli Biт kullanım davranışlarını belirlemeyi amaçlayan bu çalışmadan elde edilen sonuçlara genel olarak bakıldığında öğrencilerin belirli bir güvenli BiT kullanım davranışları gösterdiği ancak bunların gelişen ve hızla değişen teknolojik koşulların oluşturduğu yeni durumlara yanıt vermede yetersiz olduğu görülmektedir. Yapılan analiz sonuçları öğrencilerin bilgisayara erişim güvenliği, zararlı programlar ve korunma yolları, sosyal mühendislik, parola güvenliği, dosya erişim ve paylaşım güvenliği, internet ve ağ güvenliği, e-posta güvenliği, yedekleme yapma konularında temel düzeyde ve en popüler olarak bilinen güvenlik önlemlerinden yalnızca bir ya da birkaçını aldığını, diğer güvenlik önlemlerini ise almadıklarını göstermektedir. Öğrencilerin diğer güvenlik önlemlerini almamalarının temelinde yatan neden öğrencilerin ek güvenlik tedbirlerini bilmemeleri ve/veya tek bir güvenlik önlemi almanın bilgi güvenliğini sağlamada yeterli olacağını düşünmeleri olabilir. Örneğin, öğrencilerin büyük çoğunluğu zararlı programlardan korunmak için antivirüs programı kullanarak önlem aldıklarını düşünmekte ve antivirüs programı kullanımı dışındaki güvenlik önlemlerini çok az öğrencinin aldığı görülmektedir. Ayrıca öğrencilerin bilgi güvenliğini sağlamak adına yaptıkları doğru bilinen bazı hatalı davranışlar bilgi güvenliğini riske sokabilmektedir. Bu nedenle söz konusu konularla ilgili öğrenci bilgi ve farkındalığının artırılarak bunun davranışa dönüştürülmesi bilişim teknolojileri öğretmenlerine düşen önemli bir sorumluluktur.

Araştırma bulguları, bilgisayara başkalarının erişimini engellemek adına öğrencilerin yaklaşık olarak yarısının kullanııı adı ve parola kullanımı ile önlem aldıklarını; ancak çok az öğrencinin bilgisayarını başkalarıyla ortak kullanmamaya dikkat ettiğini göstermektedir. Dolayısıyla ortak kullanım yapılması durumunda erişim güvenliğini sağlamada parola ile önlem almanın etkisi de azalacaktır. Bunun dışında antivirüs programı, güvenlik duvarı kullanımı, bilgisayarın başından kalkınca oturumu şifre ile kapatma, bilgisayarın fiziksel güvenliğini sağlama gibi önlemlere ise çok fazla dikkat etmediklerini göstermektedir. Bu nedenle bilgisayarın fiziksel güvenliği ve erişim güvenliğini sağlamak adına kullanıcı adı ve parola kullanımı dışındaki önlemler konusunda öğrencilerin bilgi ve farkındalıklarının artıııması faydalı olacaktır.

Araştırma bulgularına göre öğrencilerin çoğunluğu zararlı programlardan korunmak adına antivirüs programları kullandıklarını belirtmiştir. Ancak bulgular öğrencilerin antivirüs programlarını düzenli olarak güncellemediklerini ve bu konuya çok fazla önem vermediklerini 
göstermektedir. Gelişen teknolojiye bağlı olarak zararlı programlara her gün bir yenisinin eklenmesi ise güncelleme işleminin ne kadar önemli olduğuna işaret etmektedir. Dolayısıyla antivirüs programı kullanımı ve güncellenmesi konularında öğrenci bilgi ve farkındalığııın artırılması gerekmektedir. Benzer şekilde bir diğer araştırma bulgusu öğrenciler arasında korsan yazılım kullanımının yaygın olduğunu göstermektedir. Bu nedenle söz konusu öğrenciler korsan yazııım kullanımından kaynaklanabilecek tehditlerle karşı karşıya kalabilirler. Bunu önlemek adına öğrencilerin zararlı programların neler olduğu, hangi yollarla bulaşabileceği ve bunlardan korunmak adına neler yapılabileceği, yasal yazılım/program kullanımının önemi ve bu konudaki yasal ve etik boyut hakkında öğrencileri bilgilendirmek önemlidir.

Araştırma bulguları öğrencilerin çoğunluğunun yedekleme yapmadığını ya da üç aydan daha uzun süreli olarak yedekleme yaptıklarını, yedekleme yapanların büyük bir kısmının ise yedeklemelerini usb belleklere ya da aynı bilgisayara yaptıklarını göstermektedir. Bu bulgular öğrencilerin yedekleme yapmaya çok fazla önem vermediğini ve yedekleme yapma konusunda doğru bilgi ve davranışları göstermediklerini ortaya koymaktadır. Örneğin usb belleklerin zararlı program bulaşma olasılığı en yüksek olan depolama ortamlarından biri olduğu dikkate alındığında bu ortamlarda yedekleme yapmanın riskler oluşturduğu göze çarpmaktadır. Bu nedenle öğrencilere verilecek olan bilgi güvenliği eğitimleri kapsamında yedekleme yapmanın önemi, ne sıklıkla ve hangi ortamlarda yedekleme yapmanın doğru olacağının açıklanması uygun olacaktır.

Araştırmadan elde edilen bir diğer sonuca göre öğrencilerin önemli bir kısmı internet ve ağ ortamında dosya paylaşımı yaptıklarını belirtmektedirler. Dosyaları paylaşıma açmadıklarını belirten öğrenciler ise bunun temel nedenini dosya paylaşımının nasıl yapılacağını bilmedikleri ve dosya paylaşımını güvenli bulmadıkları şeklinde belirtmektedir. Dosya paylaşımı yapan öğrencilerin büyük çoğunluğu ise paylaşımla ilgili herhangi bir güvenlik önlemi almadıklarını belirtmektedir. Bu nedenle öğrencilere dosya paylaşımının nasıl yapılacağı, paylaşım esnasında hangi güvenlik önlemlerinin alınması gerektiği ve nitel analiz bulgularında belirtilen bu konudaki yanlış davranışlar konusunda kullanıcıların bilinçlendirilmesi faydalı olacaktır. Ayrıca araştırmanın bir diğer sonucuna göre öğrencilerin yarısına yakını internetten video, müzik, film gibi dosya veya programları yasal siteler dışındaki sitelerden indirdiklerini belirtmiştir. Bu bulgudan hareketle öğrencilerin yasal site/program kullanımıyla ilgili etik davranışlar konusunda bilgilendirilmesinin ve yasal olmayan kaynaklardan edinilecek 
dosya ve program kullanımının verebileceği zarar konusunda farkındalıklarının artırıması yararlı olacaktır.

Araştırma bulguları öğrencilerin yaklaşık yarısının kullanıcı adı ve şifre gerektiren ortamların çoğunda benzer şifreyi kullandıklarını göstermektedir. Ayrıca öğrencilerin çok az bir kısmının parola güvenliğini sağlama konusunda; şifreyi başkalarıyla paylaşmama; harf, rakam ve özel karakter içeren şifreler kullanma; şifreyi zaman zaman güncelleme; en az sekiz karakterden oluşan şifre kullanma; şifre oluştururken deyim gibi kalıp ifadelere şifrede yer vermeme; şifre oluştururken ad, soyad, doğum tarihi, doğum yeri kişisel bilgilere şifrede yer vermeme; şifreyi ajanda gibi başkalarının görebileceği bir yerlere kaydetmeme gibi tedbirleri aldıklarını göstermektedir. Bu nedenle öğrencilere verilecek parola güvenliği ile ilgili eğitimlerde güvenli parola oluşturmada nelere dikkat edilmesi gerektiğinin açıklanması yararlı olacaktır.

Araştırma bulguları öğrencilerin çoğunun ortak kullanım alanlarından internete girdiklerini ve bu alanlarda internetten alışveriş yaptıklarını göstermektedir. Kablolu ve kablosuz ağ güvenliğinin sağlanması konusunda ise öğrencilerin yarısına yakını modem şifresini tanımadık kişiler ile paylaşmama şeklinde önlem almaktadır. Fakat modem şifresini güncelleme, şifreyi başkalarıyla paylaşmama, kullanılmayan portları kapatma gibi önlemleri ise çok az öğrencinin aldığı görülmektedir. Bu nedenle ortak kullanım alanlarında internet kullanımından, kablolu ve kablosuz ağ kullanımından kaynaklanabilecek bilgi güvenliği ihlal ve tehditlerine karşın öğrencilerin internet ve ağ güvenliği konusunda bilinçlendirilmesinin ve farkındalığının artırılmasının yararlı olacağı düşünülmektedir.

E-posta kullanımı ile ilgili bulgular incelendiğinde bazı öğrencilerin bilgi güvenliğini sağlamak adına istenmeyen e-posta alanına gelen postaları okumadan sildikleri görülmektedir. Ancak istenmeyen e-posta dışındaki postalarında istenmeyen e-posta alanına düşebileceği dikkate alındığında kullanıcılar bu konuda bilgi kayıpları yaşayabilirler. Ayrıca bulgular öğrencilerin sosyal mühendislik amaçlı gönderilen e-postaları ayırt etmede zorlandıklarını ve bu postaları dikkate alabildiklerini göstermektedir. Bu nedenle öğrencilere e-posta güvenliğinin sağlanması, sosyal mühendislikle mücadele adına neler yapılabileceği konusunda eğitimler verilmesi faydalı olacaktır.

Yukarıda belirtilen konular dışında öncelikle öğrencilere bilgi güvenliği ve önemi, bilgi güvenliği ile kullanıcı sorumluluğu hakkında bilgi verilerek bilgi güvenliğinin ne olduğu, ne tür 
davranışların güvenli nelerin güvensiz olduğu, bilgi güvenliği ihlallerin kullanıcıları ne gibi tehlikelerle karşı karşıya bırakabileceğinin, bilgi güvenliğinin sağlanması konusunda kullanıcılara ne gibi sorumluluklar düştüğü konularında farkındalıklarının artırıması gerekmektedir. Çünkü bu konuda yeterli farkındalığa sahip olmayan kullanıcıların güvenli Biт kullanım davranışlarını da göstermeyeceği düşünülmektedir.

Türk eğitim sisteminin genel amaçlarından biri de bireylerin beden, zihin, ahlâk, ruh ve duygu bakımından dengeli ve sağlıklı şekilde gelişimlerini tamamlamalarına yardımcı olmaktır. BiT'teki gelişim ve değişmelerin yansımaları sonucunda bireysel ve toplumsal hayatta önemli ve köklü değişiklikler yaşanır olmuştur. Türk eğitim sistemi de bireylerin beden, zihin, ahlâk, ruh ve duygu bakımından dengeli ve sağlıklı şekilde gelişimlerini sağlamada bu değişimlere ayak uydurmalıdır. Örneğin internet teknolojilerinin ucuzlaması ve hızlanmasına bağlı olarak hemen hemen her birey bu teknolojiyi kullanır duruma gelmiştir. Bu teknolojinin aşırı ve doğru olmayan kullanımına bağlı olarak da bireylerin çeşitli bilgi güvenliği tehdit ve saldırılar ile karşı karşıya kalmakta, bu durumun ortaya çıkması ise bireylere maddi ve manevi zararlar verebilmektedir.

Milli Eğitim Bakanlığı öğrencilerin bilgi güvenliği konusundaki farkındalıklarını artırmak amacıyla hazırlanan Bilişim Teknolojileri ve Yazılım dersi çerçeve programında öğrenci ihtiyaçlarına göre bilgi güvenliği konularında da eğitim verilmesi gerektiğini belirtmektedir (Talim ve Terbiye Kurulu Başkanlığı Kararı, 2012). Bu noktada bilgi güvenliği konusunda öğrencilerin ihtiyaçları, yaşadıkları problemlerin belirlenmesi önemlidir. Söz konusu dersler kapsamında bilgi güvenliği konularının öğretiminde bu araştırmadan elde edilen bulgular dikkate alınarak gerçekleştirilecek bilgi güvenliği eğitimlerinin öğrenci intiyaçlarına uygun olacağı düşünülmektedir.

Günümüzde Z kuşağının temsilcileri olarak adlandırılan çocukların sokakta oyun oynamak yerine tablet bilgisayarlarıyla sosyalleştikleri dikkate alındığında ihtiyaca uygun bilgi güvenliği eğitimlerinin erken yaşta verilmesinin ne denli önemli olduğu sonucuna varılmaktadır. Okul öncesi dönemden üniversiteye kadar eğitimin her sürecinde verilmesi gereken bilgi güvenliği eğitimleri ile öğrencilerin farkındalık düzeyleri artırılabilir. 


\section{KAYNAKLAR}

Adams, A. \& Sasse, M. A. (1999). Users are not the enemy. Communications of The ACM, 42(12), 40-46.

Besnard, D. \& Arief, B. (2004). Computer security impaired by legitimate users. Computers and Security, 23, 253-264.

Brostoff, S. \& Sasse, M. A. (2001). Safe and sound: A safety-critical approach to security. Proceedings New Security Paradigms Workshop, 41-47. New York: The Association for Computing Machinery Press. Web: http://citeseer.ist.psu.edu/brostoff01safe.html adresinden 3 Mayıs 2012'de alınmıştır.

Canbek, G. ve Sağıroğlu, Ş. (2006). Bilgi, bilgi güvenliği ve süreçleri üzerine bir inceleme. Gazi Üniversitesi Politeknik Dergisi, 9(3).

Canbek, G. ve Sağıroğlu, Ş. (2007). Çocukların ve gençlerin bilgisayar ve internet güvenliği. Gazi Üniversitesi Politeknik Dergisi, 10(1).

Ceylan, Y. (2013). Türkiye'de çocukların güvenliğine yönelik "güvenli internet" uygulamasının yazılı basında yankıları. Akademik Bakış Dergisi, 37.

Çelen, F. K., Çelik, A. ve Seferoğlu, S. S. (2011). Çocukların internet kullanımları ve onları bekleyen çevrim-içi riskler. XIII. Akademik Bilişim Konferansı (AB11). Inönü Üniversitesi, Malatya, 2-4.

Chou C., Chan, P. S. \& Wu, H. C. (2007). Using a two-tier test to assess students' understanding and alternative conceptions of cyber copyright laws. British Journal of Educational Technology, 38(6), 1072-1084.

Chou, C., Condron, L. \& Belland, J. C. (2005). A review of the research on internet addiction. Educational Psychology Review, 17(4), 363-388.

Colwill, C. (2009). Human factors in information security: The insider threate who can you trust these days? Information Security Technical Report, 14, 186-196.

Demirel, M., Yörük, M. ve Özkan, O. (2013). Çocuklar için güvenli internet: Güvenli internet hizmeti ve ebeveyn görüşleri üzerine bir araştırma. Mehmet Akif Ersoy Üniversitesi Sosyal Bilimler Enstitüsü Dergisi, 4(7), 54-68.

Egan, M. (2004). The executive guide to information security: Threats, challenges and solutions. Harlow: Addison-Wesley.

Ersoy, E. (2007). Gizlilik, bireysel haklar, kişisel verilerin korunması. Akademik Bilişim Konferansı 2007.

Ersoy, A. F. ve Ersoy, A. (2008). Internet ve çocuk hakları eğitimi. Web: http://ietc2008.home.anadolu.edu.tr/ adresinden 12 Kasım 2013 tarihinde alınmıştır.

Fatih Projesi Çalıştay Raporu. (2012). Web: http://fatih.inetd.org.tr/Calistay/Fatih-calistayrapor.pdf adresinden 5 Eylül 2013'de alınmıştır.

Gonzales, J. J. \& Sawicka, A. (2002). A framework for human factors in information security. Presented at the 2002 WSEAS Int. Conf. On Information Security. Rio de Janerio. Web: http://ikt.hia.no/josejg/ adresinden 2 Eylül 2013'de alınmıştır.

Hekim, H. ve Başıbüyük, O. (2013). Siber suçlar ve türkiye'nin siber güvenlik politikaları. Uluslararası Güvenlik ve Terörizm Dergisi, 4(2). 
Jones, A. \& Colwill, C. (2008). Dealing with the malicious insider. In Australian Information Security Management Conference (p. 52).

Kaşıkçı, D. N., Çağıltay, K., Karakuş, T., Kurşun, E. ve Ogan, C. (2014). Türkiye ve avrupa'daki çocukların internet alışkanlıkları ve güvenli internet kullanımı. Eğitim ve Bilim, 39(171).

Koç, S. ve Kaynak, S. (2010). Bilişim suçları bağlamında yeni medya olarak internet ve kişisel güvenlik. Akademik Bilişim Konferansı 2010.

Mahabi, V. (2010). Information security awareness: system administrators and end-users perspectives at florida state university. Electronic Theses, Treatises and Dissertations.

Markotten, D. G. (2002). User-centered security engineering. Web: http://tserv.iig.unifreiburg.de/telematik/atus/publications/Ge2002.pdf adresinden 12 Ağustos 2013'de alınmıştır.

Maxion, R. A. \& Reeder, R. W. (2005). Improving user-interface dependability through mitigation of human error. International Journal of Human Computer Studies, 63(1-2), 25-50.

Mart, i. (2012). Bilişim kültüründe bilgi güvenliği farkındalığı. Yüksek Lisans Tezi, Kahramanmaraş Sütçü İmam Üniversitesi Fen Bilimleri Enstitüsü.

Öğün, M. N. ve Kaya, A. (2013). Siber güvenliğin milli güvenlik açısından önemi ve alınabilecek tedbirler. Güvenlik Stratejileri Dergisi, 18, 145-181.

Poulsen, K. (2000). Mitnick to lawmakers: People, phones and weakest links. Web: http://www.politechbot.com/p-00969.html adresinden 13 Mart 2013'de alınmıştır.

Şahinaslan, E., Kandemir, R. ve Şahinaslan, Ö. (2009). Bilgi güvenliği farkındalık eğitim örneği. XI. Akademik Bilişim Konferansı Bildirileri, Şanlıurfa.

Şahinaslan, E., Kantürk, A., Şahinaslan, Ö. ve Borandağ, E. (2009). Kurumlarda bilgi güvenliği farkındalı̆̆ı, önemi ve oluşturma yöntemleri. XI. Akademik Bilişim Konferansı Bildirileri, Şanlıurfa.

Talim ve Terbiye Kurulu Başkanlığı Kararı (2012). Web: http://ttkb.meb.gov.tr/ adresinden 26 Şubat 2014' tarihinde alınmıştır.

Tekerek, M. (2008). Bilgi güvenliği yönetimi. KSÜ Fen ve Mühendislik Dergisi, 11(1), 132.

Vroom, C. \& Von Solms, R. (2004). Towards information security behavioural compliance. Computers and Security, 23(3), 191-198.

Vural, Y. ve Sağıroğlu, Ş. (2008). Ülke bilgi güvenliği. 3. Uluslararası Katılımlı Bilgi güvenliği ve Kriptoloji konferansı, 25-27 Aralık 2008, Ankara.

Wagner, A. E. \& Brooke, C. (2007). Wasting time: The mission impossible with respect to technology-oriented security approaches electronic. Journal of Business Research Methods, 5(2), 117-124.

Wishart, J. M., Oades, C. E. \& Morris, M. (2007). Using online role play to teach internet safety awareness. Computers \& Education, 48(3), 460-473.

Yavanoğlu, U., Sağıroğlu, Ş. ve Çolak, í. (2012). Sosyal ağlarda bilgi güvenliği tehditleri ve alınması gereken önlemler. Gazi Üniversitesi Politeknik Dergisi, 15(1).

Zeydan, Ö. (2006). Kişisel bilgisayarlar ve internet güvenliği. XI. "Türkiye'de internet" Konferansı, 21 - 23 Aralık 2006, TOBB Ekonomi ve Teknoloji Üniversitesi, Ankara. 


\section{SUMMARY}

It is seen that most of the studies towards ensuring information security are on such methods as security walls, strong authentication methods and safety models; and technical studies towards developing software. It is also seen that some of the studies carried out are on penal policies and sanctions, directives and developing models on information security. In the literature, very few studies are found on determining the errors caused by human factor and on removing these errors. When the fact that the weakest link in information security chain is human, it is understood that more attention should be paid on determining information security mistakes and violations caused by human and on resolving these mistakes and violations. The fact that it is human beings who develop, manage and use security systems, for which big investments are made, the human factor goes beyond the technical dimension in ensuring information security.

Preventing human-based mistakes and violations in protecting institutions and users against information security threats is of great importance. At this point, it is necessary to train and improve the awareness of both institutions and individuals on information security threats. When all these are taken into account, this current study will work on identifying information security mistakes and violations of students studying at higher education programmes and forming the objective and scope of the information security trainings to be provided in line with the needs and deficiencies to be presented. The study was conducted on 124 first year students. When Table 1 is examined, it is seen that almost $60 \%$ of the sample group were female students while $40 \%$ were male students. It is also seen that $70 \%$ of the students are between $16-20$ years of age while $30 \%$ are $21-25$ years of age. $80 \%$ of the students in the sample group have computers while $20 \%$ did not. Moving from this data, it is seen that the sample group on which information security study has been carried out are young adults who have computer and similar devices. Data were analyzed using the qualitative and quantitative methods.

When the results of the current study, which aims to determine the information security mistakes and violations of students studying at higher education programmes, are examined it is seen that students have a certain level of awareness on information security, however, this level of awareness is inadequate to respond to the new situations that occur as a result of rapidly growing and changing technology. The results of the analyses carried out shows that students take basic safety measures on such issues as computer access safety, password security, uploading and updating software, file access and sharing security, backup, detrimental programmes, social engineering, internet and network safety, security walls, protection, web safety, e-mail safety, modem safety and that they only take one or a few most well-known measures and that they do not take other safety measures. Among the main reasons behind the fact that students do not take other safety measures are students do not know these measures and the misconception that taking one measure would be enough. While 
this is the case concerning the adult learners at higher education, the case for learners at lower levels of education is believed to be a lot more worrying.

The results of the study showed that almost $15 \%$ of the students did not use an antivirus software; while almost $14 \%$ of them never updated their anti-virus software; almost $50 \%$ of the them did not always pay attention to whether the web site or program is secure when they entered a web site or used a program. Besides, it is seen that almost $15 \%$ of the students opened the e-mails intended for social engineering. It is also found in the study that almost $40 \%$ of the students used piracy software. The results of the study also reveal that almost $20 \%$ of the students shared filed and almost $80 \%$ did not. Among the reasons of not sharing files is facing with information security threats, which is remarkable. According to another result of the study, almost $54 \%$ of the students said that they used the same password in different mediums. Based on this result, password of a student who shares their password belonging to a system or whose password belonging to a system has been hacked will be under the risk. Almost $29 \%$ of the students in the study said that they did shopping online. This result is a finding which shows why information security factors should be paid attention to. Possible mistakes during shopping might lead to both financial losses and intangible damages. According to another finding of the study, almost $66 \%$ of the students use internet in public areas. This result emphasizes the significance of information security measures to be followed while accessing internet in public areas.

The results from the study reveal that most of the students at higher education institutions take information security measures at basic level but that these measures are only at basic level and they do not take more than one measure. Considering the fact that the sample group on which this study had been carried out was university students, it is predicted that the results would be more negative. Taking the fact that today's Z generation is socializing via IPad instead of tipcat, the importance of providing information security trainings at early ages becomes clear. Through information security trainings which should be provided at every phase of education from preschool education until university education could increase students' level of awareness. 